cambridge.org/wsc

\section{Review}

Cite this article: Maroli AS, Gaines TA, Foley ME, Duke SO, Doğramacı M, Anderson JV, Horvath DP, Chao WS, Tharayil N (2017) Omics in Weed Science: A Perspective from Genomics, Transcriptomics, and Metabolomics Approaches. Weed Sci 66: 681-695. doi: 10.1017/wsc.2018.33

Received: 8 February 2018

Revised: 5 May 2018

Accepted: 10 May 2018

\section{Key words:}

Dormancy; herbicide resistance; integrated omics; natural products; omics techniques; phytotoxins; QTL mapping; RNA-Seq; systems biology

\section{Author for correspondence:}

Nishanth Tharayil, Department of Plant and Environmental Sciences, 105 Collings Street, Clemson University, Clemson, SC 29634. (Email: ntharay@clemson.edu) (c) Weed Science Society of America, 2018. This is an Open Access article, distributed under the terms of the Creative Commons Attribution-NonCommercial-NoDerivatives licence (http://creativecommons.org/licenses/ by-nc-nd/4.0/), which permits non-commercial re-use, distribution, and reproduction in any medium, provided the original work is unaltered and is properly cited. The written permission of Cambridge University Press must be obtained for commercial re-use or in order to create a derivative work.

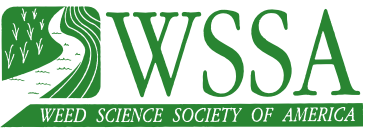

\title{
Omics in Weed Science: A Perspective from Genomics, Transcriptomics, and Metabolomics Approaches
}

\author{
Amith S. Maroli ${ }^{1}$, Todd A. Gaines ${ }^{2}$, Michael E. Foley ${ }^{3}$, Stephen O. Duke ${ }^{4}$, \\ Münevver Doğramacı ${ }^{5}$, James V. Anderson ${ }^{6}$, David P. Horvath ${ }^{7}$, Wun S. Chao ${ }^{8}$ \\ and Nishanth Tharayil ${ }^{9}$
}

\begin{abstract}
${ }^{1}$ Postdoctoral Fellow (ORCID: 0000-0002-0647-0316), Department of Plant and Environmental Sciences, Clemson University, Clemson, SC, USA; current: Department of Environmental Engineering and Earth Sciences, Clemson University, Anderson, SC, USA, ${ }^{2}$ Assistant Professor (ORCID: 0000-0003-1485-7665), Department of Bioagricultural Sciences and Pest Management, Colorado State University, Fort Collins, CO, USA, ${ }^{3}$ Plant Physiologist, Red River Valley Agricultural Research Center, Sunflower and Plant Biology Research Unit, USDAAgricultural Research Service, Fargo, ND, USA, ${ }^{4}$ Research Leader (ORCID: 0000-0001-7210-5168), Natural Products Utilization Research Unit, National Center for Natural Products Research, USDA-Agricultural Research Service, University, MS, USA, ${ }^{5}$ Research Molecular Biologist (ORCID: 0000-0002-1412-8174), Red River Valley Agricultural Research Center, Sunflower and Plant Biology Research Unit, USDA-Agricultural Research Service, Fargo, ND, USA; current: University of South Dakota, Sanford School of Medicine, Internal Medicine Department, Sioux Falls, SD, USA, ${ }^{6}$ Research Chemist (ORCID: 0000-0002-1801-5767), Red River Valley Agricultural Research Center, Sunflower and Plant Biology Research Unit, USDA-Agricultural Research Service, Fargo, ND, USA, ${ }^{7}$ Research Plant Physiologist (ORCID: 0000-0002-8458-7691), Red River Valley Agricultural Research Center, Sunflower and Plant Biology Research Unit, USDA-Agricultural Research Service, Fargo, ND, USA, ${ }^{8}$ Research Molecular Geneticist, Red River Valley Agricultural Research Center, Sunflower and Plant Biology Research Unit, USDA-Agricultural Research Service, Fargo, ND, USA and ${ }^{9}$ Associate Professor (ORCID: 0000-0001-6866-0804), Department of Plant and Environmental Sciences, Clemson University, Clemson, SC, USA
\end{abstract}

\begin{abstract}
Modern high-throughput molecular and analytical tools offer exciting opportunities to gain a mechanistic understanding of unique traits of weeds. During the past decade, tremendous progress has been made within the weed science discipline using genomic techniques to gain deeper insights into weedy traits such as invasiveness, hybridization, and herbicide resistance. Though the adoption of newer "omics" techniques such as proteomics, metabolomics, and physionomics has been slow, applications of these omics platforms to study plants, especially agriculturally important crops and weeds, have been increasing over the years. In weed science, these platforms are now used more frequently to understand mechanisms of herbicide resistance, weed resistance evolution, and crop-weed interactions. Use of these techniques could help weed scientists to further reduce the knowledge gaps in understanding weedy traits. Although these techniques can provide robust insights about the molecular functioning of plants, employing a single omics platform can rarely elucidate the gene-level regulation and the associated real-time expression of weedy traits due to the complex and overlapping nature of biological interactions. Therefore, it is desirable to integrate the different omics technologies to give a better understanding of molecular functioning of biological systems. This multidimensional integrated approach can therefore offer new avenues for better understanding of questions of interest to weed scientists. This review offers a retrospective and prospective examination of omics platforms employed to investigate weed physiology and novel approaches and new technologies that can provide holistic and knowledge-based weed management strategies for future.
\end{abstract}

\section{Introduction}

The identities of all organisms are embedded in their genes, which are often influenced by developmental and environmental cues. Sequential and temporal decoding of these genes confers physiological distinctiveness to each individual (Anderson 2008). In the last two decades, the term "omics" has been suffixed with several fields of study in biology (Brunetti et al. 2018). Recent advances in high-throughput functional omics technologies (Table 1) have facilitated an understanding of the various molecular-environmental interactions that regulate biological systems (Kitano 2002). The use of omics techniques to study various biological aspects would provide greater opportunities to dissect the molecular and physiological 
Table 1. Examples of applications of omics approaches in plant systems biology research.

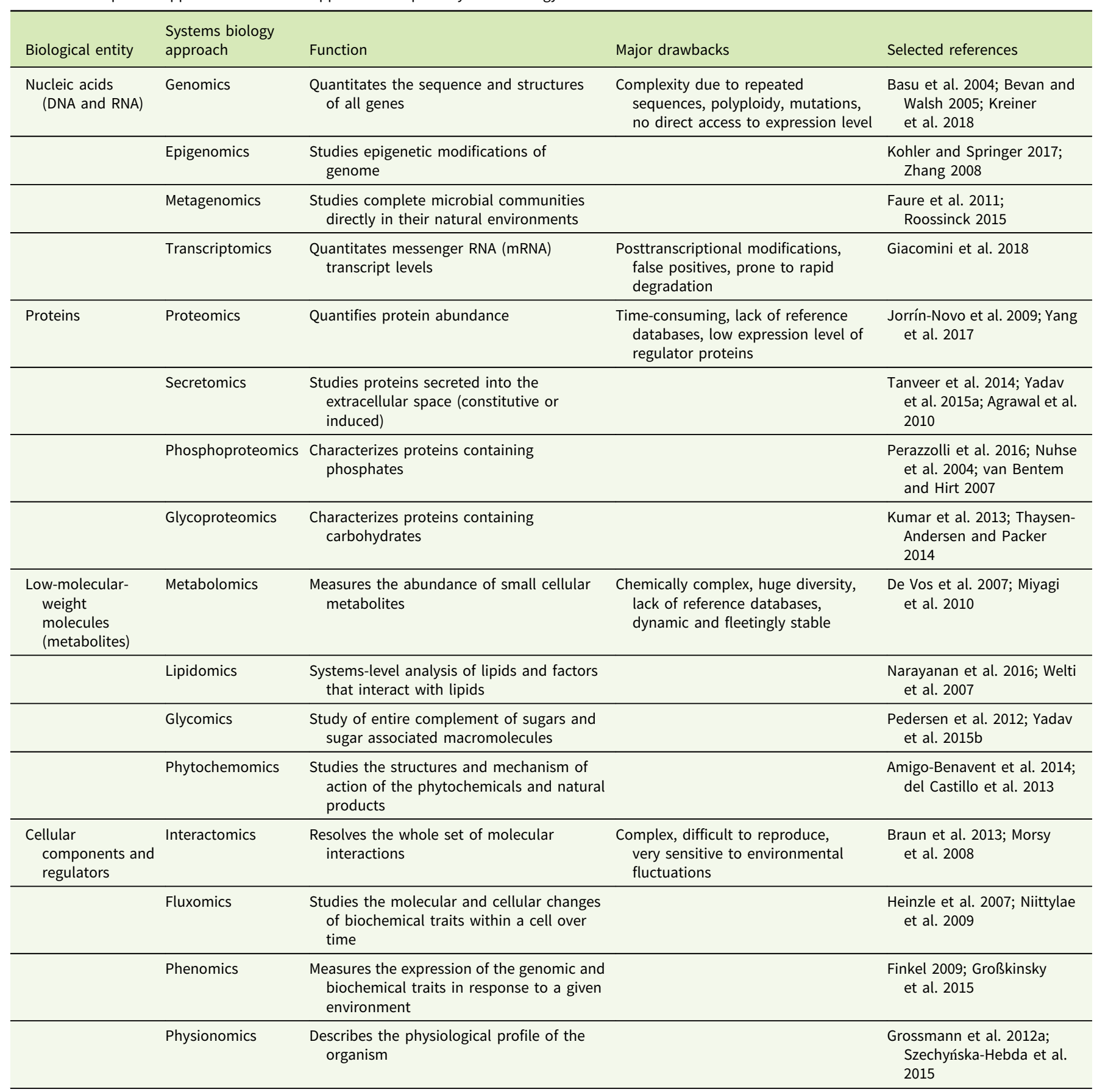

mechanisms in developing resilient phenotypes. Among the various omics platforms, functional genomics has seen rapid progress, resulting in a growing number of sequenced plant genomes. This has facilitated the development of plants selected for specific agronomic traits and biological processes (Kantar et al. 2017; Nelson et al. 2018). The traditional giants of omics platforms encompass genomics, transcriptomics, and proteomics (Palsson 2002; Rochfort 2005). While genomics aims to understand how the genome functions, transcriptomics and proteomics perform systematic qualitative and quantitative analysis of the transcriptome and proteome content, respectively, in a tissue, cell, or subcellular compartment. Other recent omics techniques such as metabolomics, phenomics, and lipidomics complement the traditional techniques to depict a precise picture of the entire cellular process.

Omics approaches in weeds science have been gaining momentum over the past decade. As with other domains, the number of studies using genomic approaches to investigate weed biology and physiology has increased over the years (Basu et al. 2004; Chao et al. 2005; Guo et al. 2017; He et al. 2017; Kreiner et al. 2018; Molin et al. 2017; Olsen et al. 2007; Tranel and Horvath 2009). DNA-based molecular studies using simple sequence repeats (SSRs), microsatellites, amplified fragment length polymorphisms (AFLPs), and inter simple sequence repeats (ISSRs) have provided tremendous opportunities to study weedy characteristics such as resilience, dormancy, and 
invasiveness, as well as weed genetic diversity and hybridization among related weed species (Corbett and Tardif 2006; Horvath 2010). Excellent reviews on weed genomics and DNA-based herbicide-resistance techniques have been produced by Basu et al. (2004), Corbett and Tardif (2006), Stewart (2009), and Tranel and Horvath (2009). Recently, the weed science community has initiated the International Weed Genomics Consortium to facilitate genomics for weed science (Ravet et al. 2018). However, applications of other omics for studying agronomically important weeds are at a nascent stage, as seen by the limited number of published studies (Table 2).

In addition to genomics, other omics techniques have also been used to investigate areas critical to weed science, including stress response, weediness/invasiveness, herbicide resistance, and genetic diversity (Délye 2013; Grossmann et al 2010; Keith et al 2017; Stewart 2009; Stewart et al. 2009, 2010; Zhang and Reichers 2008). However, due to the complexity of the molecular and environmental interactions, no single omics analysis can independently explain the intricacies of fundamental physiology (Fukushima et al. 2009; Hirai et al. 2004; Liberman et al. 2012). Hence, an integrated systems biology approach is needed to provide precise information about the molecular, biochemical, and physiological status of the target organism (Figure 1). An integrated systems biology approach can help not only in annotating unknown genes, but also in identifying their regulatory networks and the metabolic pathways they would influence
(Pérez-Alonso et al. 2018). This would aid in understanding the genotype-phenotype relationship and consequently help to improve the existing weed management strategies in agricultural fields. Although there are several omics platforms, the present review will strive to highlight omics approaches used to study physiological aspects of agriculturally important weeds that have not been previously touched upon, such as elucidating physiology of bud dormancy, deciphering the mechanisms of herbicide resistance, and identifying potential herbicidal phytochemicals using omics approaches.

\section{Transcriptomics to Investigate Herbicide Resistance}

Compared with the availability of genome sequence information and genetic resources for model plants such as mouse-ear cress [Arabidopsis thaliana (L.) Heynh.] (Arabidopsis Genome Initiative 2000), barrelclover (Medicago truncatula Gaertn.) (Bell et al. 2001), and purple false brome [Brachypodium distachyon (L.) P. Beauv.] (Vogel et al. 2010) and the genome sequences of several other dicot and monocot crops that are either sequenced or soon will be, to date only four draft genome assemblies have been completed for agronomic weed species (Table 3). Next-generation sequencing (NGS) techniques such as RNA-Seq have enabled accurate and powerful transcriptome analysis approaches for non-model species such as weeds, without requiring a fully assembled genome. A review of 15 RNA-Seq studies conducted in

Table 2. Examples of omics papers on phytotoxins, including herbicides.

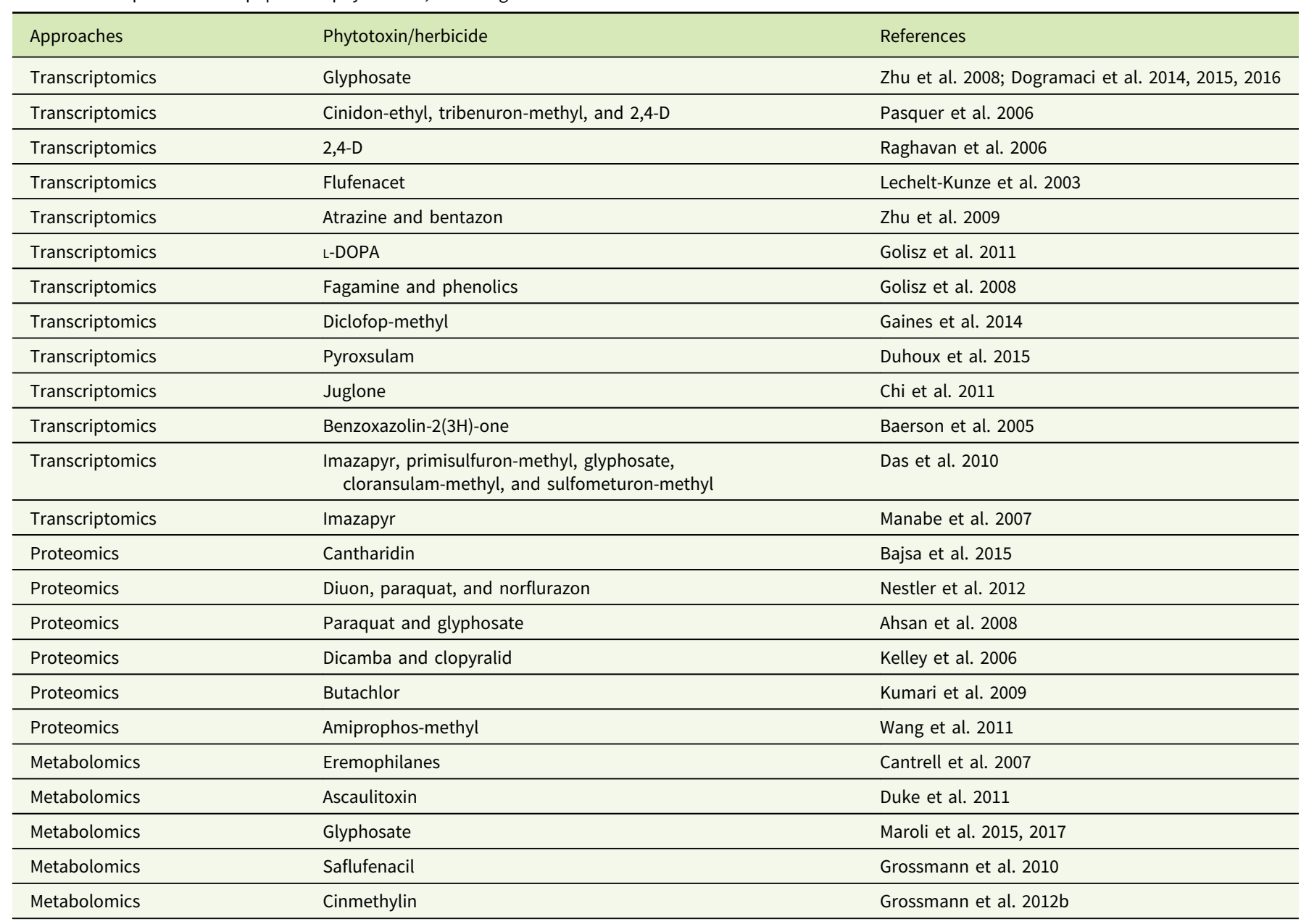




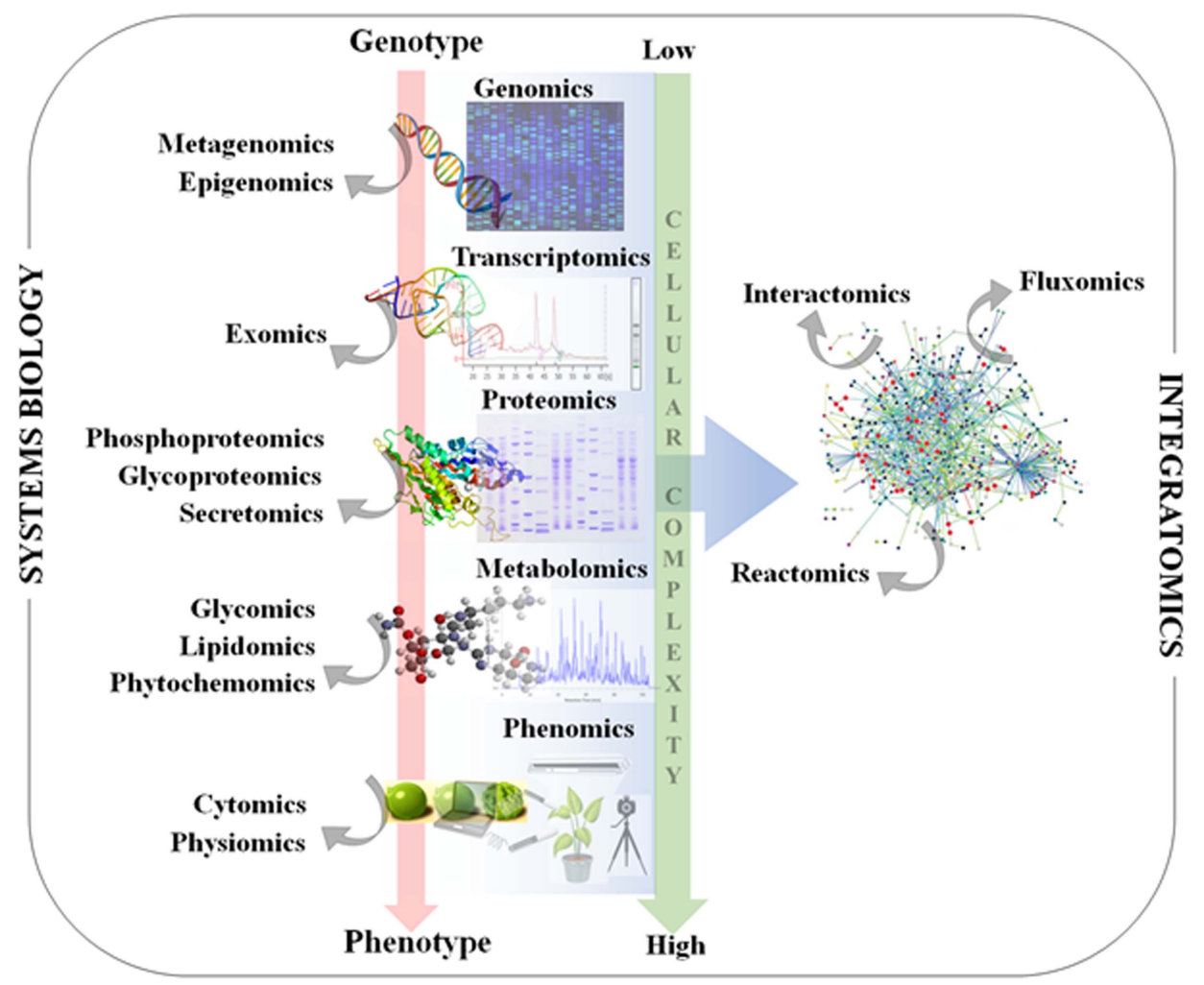

Figure 1. Classical systems biology concept and omics organization. The central dogma of molecular biology covers the progressive functionalization of the genotype to the phenotype. The omics techniques track and capture various molecular entities across the biological system.

weeds to find candidate genes for herbicide resistance and abiotic stress tolerance identified that increased replicate number and controlling genetic background were important factors to increase detection power and minimize the false-discovery rate (Giacomini et al. 2018). The first weed species transcriptomes released were horseweed (Erigeron canadensis L.) (Peng et al. 2010) and waterhemp [Amaranthus tuberculatus (Moq.) J. D. Sauer] (Riggins et al. 2010), with at least 22 weed transcriptomes sequenced and assembled to date, including weeds of agronomic crops, turfgrass, and invasive weeds (Gaines et al. 2017; McElroy 2018). Compared with transcriptomics methods such as microarray, which provide relative quantification, NGS-based transcriptome approaches produce absolute quantification of transcript expression as well as the sequence of all transcripts in a given sample. All expressed genes can be studied for changes in regulation (for example, upregulation of cytochrome P450s to increase herbicide metabolism), and several genes can be examined for candidate nonsynonymous mutations that could confer resistance. The identification of transcripts with differential regulation and/or mutations generates a hypothesis to be tested with subsequent validation. For discussion about transcriptomics in weeds before the introduction of NGS, the reader is referred to reviews by Lee and Tranel (2008) and Horvath (2010).

RNA-Seq measures the transcriptome abundance at a given time from a genome. The data can be used for various analyses, such as identification of differentially expressed transcripts

Table 3. Draft genome assemblies of agronomic weed species sequenced using next-generation sequencing technologies.

\begin{tabular}{|c|c|c|c|c|c|c|}
\hline Agronomic weed & Plant line & $\begin{array}{l}\text { Estimated } \\
\text { genome size }\end{array}$ & $\begin{array}{l}\text { Sequence } \\
\text { coverage }\end{array}$ & $\begin{array}{l}\text { Genome } \\
\text { coverage }\end{array}$ & Sequencing platforms & References \\
\hline $\begin{array}{l}\text { Wild radish } \\
\text { (Raphanus } \\
\text { raphanistrum L.) }\end{array}$ & 5th generation inbred & $515 \mathrm{Mb}$ & NA & $49.3 \%$ & Illumina Genome Analyzer II & $\begin{array}{l}\text { Moghe et al. } \\
2014\end{array}$ \\
\hline $\begin{array}{l}\text { Horseweed } \\
\quad \text { (Erigeron canadensis L.) }\end{array}$ & $\begin{array}{l}\text { Tennessee glyphosate- } \\
\text { resistant biotype (TN-R) }\end{array}$ & $335 \mathrm{Mb}$ & $350 x$ & $92.3 \%$ & $\begin{array}{l}\text { Roche } 454 \text { GS-FLX, Illumina } \\
\text { HiSeq 2000, and } \\
\text { PacBio }^{\oplus S} \text { RS }\end{array}$ & $\begin{array}{l}\text { Peng et al. } \\
2014\end{array}$ \\
\hline $\begin{array}{l}\text { Barnyardgrass } \\
\text { [Echinochloa crus- } \\
\text { galli (L.) P. Beauv.] }\end{array}$ & STB08 & $1.41 \mathrm{~Gb}$ & $171 x$ & $90.7 \%$ & $\begin{array}{l}\text { Illumina HiSeq } 2000 \\
\text { and PacBio }{ }^{\infty} \text { RS II }\end{array}$ & $\begin{array}{l}\text { Guo et al. } \\
2017\end{array}$ \\
\hline
\end{tabular}


between treatments, analysis of sequence variants, or characterization of alternative splicing. Due to its digital nature, RNA-Seq has a linear-detection dynamic range over five orders of magnitude, enabling quantification of even transcripts with very low expression. A typical RNA-Seq experiment consists of the steps outlined in Figure 2. Numerous downstream transcriptome data analyses can also be used to help interpret data, such as identification of enriched pathways with differentially expressed transcripts. RNA-Seq is also advantageous for studying complex gene families, such as those involved in enhanced metabolic resistance (for example, cytochrome P450s, glutathione-S-transferases, glucosyl transferases, $\mathrm{ABC}$ transporters). The results of the RNA-Seq experiments alone are not sufficient to prove causation for a candidate mechanism. RNA-Seq should be considered an experimental approach to generate robust hypotheses for candidate gene function. Subsequent forward genetics validation experiments are essential to prove function, such as testing

Designing Experiment

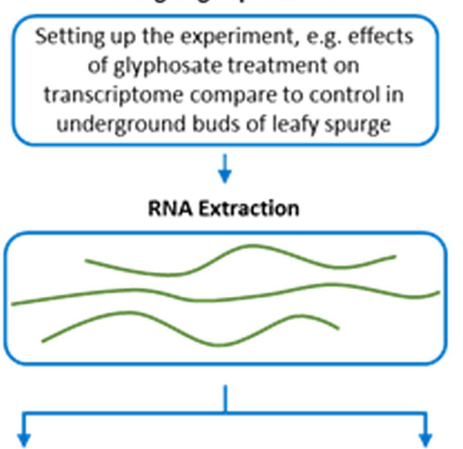

RNAseq

Library Preparation
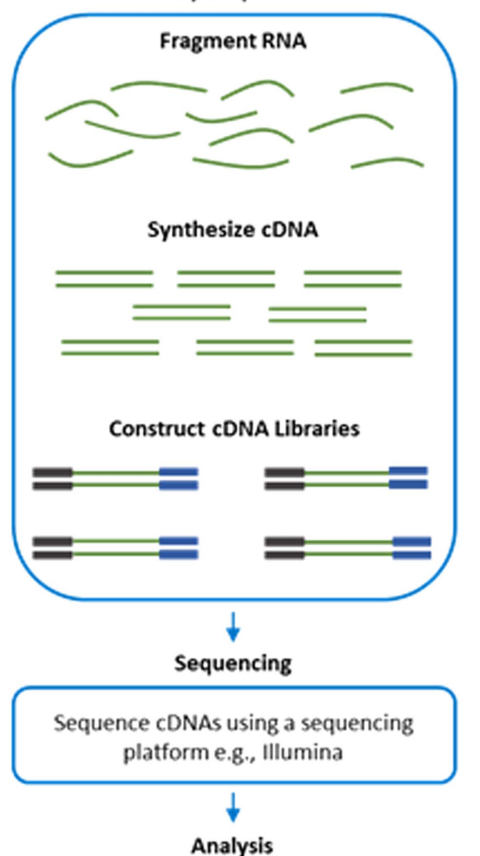

Analyze the resulting short-read sequences using bioinformatics tools, calculate differentially expressed genes, identify enriched pathways, etc.
qRT-PCR

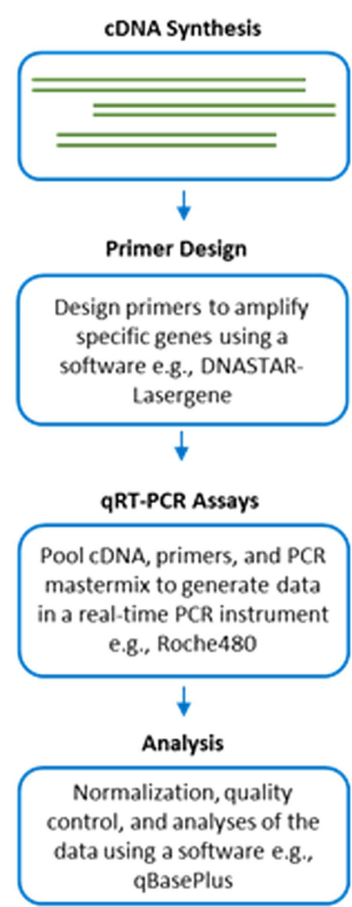

Figure 2. Workflow of transcript analyses by RNA-Seq and qRT-PCR. cosegregation of a molecular marker (increased gene expression and/or a mutation) with resistance, testing for the presence of the molecular marker in unrelated populations of the same species, and preferably expression or knockout in a heterologous system such as Arabidopsis or yeast (for example, Cummins et al. 2013; LeClere et al. 2018). Differential expression can then be measured on validation samples using $\mathrm{qRT}-\mathrm{PCR}$ on $\mathrm{CDNA}$.

In weed science, several transcriptomic studies have focused on herbicide-resistance traits, including target-site resistance mechanisms (Riggins et al. 2010; Wiersma et al. 2015; Yang et al. 2013) and non-target site resistance (NTSR) mechanisms (An et al. 2014; Gaines et al. 2014; Gardin et al. 2015; Leslie and Baucom 2014; Peng et al. 2010; Riggins et al. 2010; Yang et al. 2013). Studying the entire transcriptome is especially useful for NTSR mechanisms, because NTSR generally involves multiple genes and gene families (Délye 2013). Examples of RNA-Seq studies on NTSR in grasses include acetyl-CoA carboxylase (ACCase)-inhibitor resistance in rigid ryegrass (Lolium rigidum Gaudin) (Gaines et al. 2014) and Brachypodium hybridum Catalán, Joch. Müll., L.A. Mur \& T. Langdon (Matzrafi et al. 2017) and acetolactate synthase (ALS)-inhibitor resistance in $L$. rigidum (Duhoux et al. 2015) and blackgrass (Alopecurus myosuroides Huds.) (Gardin et al. 2015). Both NTSR and target-site mechanisms were evaluated in barnyardgrass [Echinochloa crusgalli (L.) P. Beauv.], using NGS to identify candidate genes involved in ALS-inhibitor and synthetic auxin (quinclorac) resistance (Yang et al. 2013). Responses to glyphosate and glyphosate resistance have also been studied using RNA-Seq in tall morningglory [Ipomoea purpurea (L.) Roth] (Leslie and Baucom 2014) and kochia [Bassia scoparia (L.) A. J. Scott] (Wiersma et al. 2015). Employing differential expression (DE) analysis using RNA-Seq, the study by Leslie and Baucom (2014) found a range of candidate genes that may explain differences in glyphosate response between populations, including metabolism, signaling, and defense-related genes with differential expression. Similarly, in glyphosate-resistant $B$. scoparia, RNA-Seq was used to confirm overexpression of 5-enolpyruvylshikimate-3-phosphate synthase (EPSPS) due to gene amplification, to determine that no other genes in the shikimate pathway besides EPSPS were differentially expressed between resistant and susceptible populations, and to establish that no candidate resistance-conferring mutations were present in the EPSPS sequence from the resistant population (Wiersma et al. 2015). This mutation analysis is referred to as deep sequencing, and it is used to identify mutations that may be expressed at a low level and not detected by traditional sequencing approaches. Recently, a mutation for dicamba resistance in B. scoparia was identified using transcriptomics and subsequently functionally validated using forward genetics and expression in heterologous systems (LeClere et al. 2018)

\section{Transcriptomics to Investigate Bud Dormancy and Vegetative Growth}

Early studies on bud dormancy employed traditional or accessible molecular approaches (Anderson et al. 2005; Horvath and Anderson 2002; Horvath et al. 2002). However, accessibility of the genome sequence for $A$. thaliana (Arabidopsis Genome Initiative 2000) and availability and adoption of cDNA microarray technology for plant genes (Schena et al. 1995) allowed researchers to examine transcriptome profiles for a variety of tissues and treatments and enabled the development of cross-species 
adoption of Arabidopsis platforms (Horvath et al. 2003). Omics approaches were employed for elucidating signals, pathways, and mechanisms governing dormancy in underground adventitious buds (UABs) of leafy spurge (Euphorbia esula L.) (Anderson and Horvath 2001; Anderson et al. 2004, 2007; Foley et al. 2013; Horvath et al. 2006, 2008). Euphorbia esula is a noxious and perennial rangeland weed that can reproduce and spread vegetatively from an abundance of UABs (Anderson et al. 2005). As dormancy in these buds often contributes to escape from control measures, it is essential to understand the seasonal dormancy cycles (paradormancy, endodormancy, and ecodormancy) for UABs. Horvath et al. (2006, 2008) studied the transcriptome of E. esula UABs during transitions in these well-defined phases of dormancy under greenhouse and field conditions using highdensity microarrays constructed from an E. esula expressed sequence tag database (Anderson et al. 2007). This work helped to identify transcripts encoded by a gene with similarity to DORMANCY ASSOCIATED MADS-BOX, which has since been strongly implicated in dormancy processes of several perennial plant systems (Horvath 2015). Meta-analysis of microarray-based transcriptome data also identified transcripts similar to Arabidopsis COP1, HY5, MAF3-like, RD22, and RVE1 as potential molecular markers for endodormancy in E. esula UABs (Doğramacı et al. 2015).

Studies have also been done to determine the impact of growth regulators on dormancy by examining changes in transcriptome profiles of E. esula UABs in response to foliar glyphosate treatment (Doğramac1 et al. 2014, 2015, 2016). Although glyphosate is widely used as a broad-spectrum herbicide (Duke and Powles 2008), it is also known to have hormetic activity (Belz and Duke 2014; Velini et al. 2008). When applied at sublethal concentrations, it can cause tillering in some plant species due to axillary and root-bud growth. Maxwell et al. (1987) reported that glyphosate application at higher rates $\left(\sim 2\right.$ to $\left.6 \mathrm{~kg} \mathrm{ae} \mathrm{ha}^{-1}\right)$ to E. esula under field conditions caused an increase in the number of stems per square meter as a result of shoot growth from UABs, a phenomenon referred to as "witches' brooming." Discovery or development of a growth regulator that could induce or inhibit shoot growth from UABs would be a significant step toward longterm control of other perennial weeds such as Canada thistle [Cirsium arvense (L.) Scop.], field bindweed (Convolvulus arvensis L.), and hedge bindweed [Calystegia sepium (L.) R. Br.]. Initial studies conducted using qRT-PCR, indicated that glyphosate had the most significant impact on abundance of ENT-COPALYL DIPHOSPHATE SYNTHETASE 1, which is involved in a committed step for gibberellic acid (GA) biosynthesis, and auxin transporters, including PINs, PIN-LIKES, and ABC TRANSPORTERS. Foliar glyphosate treatment also reduced the abundance of transcripts involved in cell cycle processes, which was consistent with altered growth patterns (Doğramacı et al. 2014).

RNA-Seq identified nearly 13,000 differentially expressed transcripts in UABs in response to foliar glyphosate treatment (Doğramac1 et al. 2015). Of these transcripts, 6,239 had significant changes $\geq 2$-fold in either direction, which included transcripts associated with many processes involving shoot apical meristem maintenance and stem growth. The foliar glyphosate treatment increased shikimate abundance in UABs before decapitation of aboveground shoots, indicating that EPSPS, the target site of glyphosate, was inhibited. Interestingly, the abundance of shikimate in new aerial shoots (6 wk after growthinducing decapitation) derived from UABs of foliar glyphosatetreated plants was similar to controls. The abundance of transcripts (i.e., EPSPS, EMB1144, SK1) involved in various stages of chorismate/shikimate biosynthesis had little change in amplitude, indicating glyphosate was not directly affecting transcription for components of the pathway in these tissues. Hormone analyses indicated that auxins, gibberellins (precursors and catabolites of bioactive gibberellins), and cytokinins (precursors and bioactive cytokinins) were more abundant in the aboveground shoots derived from UABs of glyphosate-treated plants versus the control. Based on the accumulation of transcriptome and metabolite data, it was proposed that the classic stunted and bushy phenotypes resulting from vegetative reproduction of $E$. esula $\mathrm{UABs}$ following foliar glyphosate treatment involve complex interactions, including shoot apical meristem maintenance, hormone biosynthesis and signaling (auxin, cytokinins, gibberellins, and strigolactones), cellular transport, and detoxification mechanisms (Doğramacı et al. 2015).

An expanded investigation into glyphosate-induced witches' brooming under field conditions was accomplished (Doğramac1 et al. 2016). Field plots treated with high rates $(3.3$ and $6.7 \mathrm{~kg}$ ae $\mathrm{ha}^{-1}$ ) of glyphosate had increased UAB-derived shoots displaying the stunted and bushy phenotype characteristics. qRT-PCR analysis to quantify the abundance of a selected set of transcripts in UABs of nontreated versus treated plants $\left(0\right.$ vs. $\left.6.7 \mathrm{~kg}_{\text {ae ha }}{ }^{-1}\right)$ further supported the impact that glyphosate has on molecular processes involved in biosynthesis or signaling of tryptophan or auxin, GA, ethylene, and cytokinins, as well as cell cycle processes. Moreover, these glyphosate-induced effects on vegetative growth and transcript abundance persisted in the field for at least $2 \mathrm{yr}$. Transcriptome studies have now progressed to a point where testable hypothesis-driven studies could be initiated as a step toward next-generation approaches for weed management. Though foliar application of glyphosate to E. esula causes effects that impact molecular processes in UABs, this broad-spectrum herbicide would not be ideal for manipulation of bud growth in rangeland perennial weeds due to its effect on non-target plant species. Nevertheless, this proof of concept project sets the stage to screen commercially available libraries of compounds, growth regulators, natural products, and other bioactive molecules that could be applied to perturb bud growth and shoot development.

Although transcriptome and metabolite analysis can identify potentially important signals, pathways, and molecular mechanisms involved in dormancy and glyphosate-induced witches' brooming, it is important to remember that these changes in transcript abundance do not reflect a direct association with activity occurring at the posttranscriptional levels (Beckwith and Yanovsky 2014). Moreover, as with many weedy species, the genome for E. esula has not been completely sequenced or annotated. Therefore, research employing molecular, genomics, and genetics approaches must rely on the annotated genomes of model species such as Arabidopsis.

\section{Metabolomics and Fluxomics to Understand Weed Physiology}

The realization that genes, transcripts, and proteins alone cannot completely explain several physiological responses has triggered a marked increase in employing approaches that can relate gene expression to the final phenotypic outcome. Metabolomics is one such approach that comprehensively identifies and quantitates low-molecular-weight metabolites (metabolome), thus offering a powerful approach for molecular phenotyping (Fiehn 2002). 
A common workflow for metabolomics experiments involves metabolite extraction, chromatographic separation, detection, data processing, metabolite identification, and statistical validation (Figure 3). Most often in plant metabolomics, metabolite separation is carried out by either liquid chromatography or gas chromatography followed by mass spectrometer detection (De Vos et al. 2007; Haggarty and Burgess, 2017; Maroli et al. 2015, 2017).

Metabolomics has been used in the past decade to study the mechanisms of action (MOAs) of synthetic and natural herbicidal compounds using several model plant species, such as maize (Zea mays L.) (Araníbar et al. 2001), sterile oat (Avena sterilis L.) (Aliferis and Chrysayi-Tokousbalides 2006), and Arabidopsis (Jaini et al. 2017; Sumner et al. 2015; Wu et al. 2018). However, limited studies have employed metabolomics to characterize weed physiology in response to herbicide applications (Aliferis and Chrysayi-Tokousbalides 2011; Miyagi et al. 2010), herbicideresistance mechanisms (Aliferis and Jabaji 2011; Maroli et al. 2015, 2017; Serra et al. 2015; Vivancos et al. 2011), and nontarget site herbicide-resistance mechanisms such as detoxification and metabolism (Wang et al. 2017). As reviewed earlier, application of genomics and transcriptomics has helped to identify herbicide-resistance mechanisms in some weeds (Chen et al. 2017; Délye 2013; Gaines et al. 2010; Nandula et al. 2012; Wright et al. 2018a, 2018b). Apart from this, metabolomics approaches have been recently adopted to understand effect of chemical stresses on perennial ryegrass (Lolium perenne L.) (Serra et al. 2015), to identify complementary glyphosate resistance mechanisms in Palmer amaranth (Amaranthus palmeri S. Watson) (Maroli et al. 2015), to determine glyphosate-induced global physiological perturbations in glyphosate-resistant (FernándezEscalada et al. 2016, 2017) and glyphosate-tolerant (Maroli et al. 2017) weeds, and to examine herbicide metabolism in herbicideresistant weeds (Wang et al. 2017). For determination of physiological perturbations, both Fernández-Escalada et al. (2016) and Maroli et al. (2017) investigated the metabolic changes induced in the weeds following exposure to nonlethal doses of glyphosate.

Although MOAs of most herbicides have been well identified, in many cases the sequence of phytotoxic events that result in plant death is unclear, particularly for slow-acting herbicides, which exhibit a significant time lag between herbicide application and plant death. Using genetics and biochemical and metabolic analyses, Fernández-Escalada et al. (2016) studied the physiologies of a glyphosate-resistant and glyphosate-susceptible $A$. palmeri population and offered new insights into the physiological manifestations of the evolved glyphosate resistance. The authors indicated that aromatic amino acids do not have significant regulatory effects on EPSPS protein and suggested that a constant free amino acid pool including aromatic amino acids is a key parameter in complementing glyphosate resistance by EPSPS gene amplification. Similar observations were also reported earlier by Maroli et al. (2015). By means of metabolite profiling, Maroli et al. (2015) reported that in addition to EPSPS gene amplification, glyphosate resistance in a biotype of $A$. palmeri may also be complemented by elevated antioxidant capacity, with several metabolites having known antioxidant properties elevated in the resistant biotype compared with the susceptible biotype (Maroli et al. 2015). Similarly, the study by Serra et al. (2015) challenged L. perenne grass with a panel of different chemical stressors, including glyphosate and its degradation compound AMPA, at subtoxic levels. The authors concluded that all the subtoxic chemical stresses investigated induced discrete physiological perturbations and complex metabolic shifts via multilevel MOAs. Studies have thus reported that monitoring the perturbations induced in the metabolic-pool levels following herbicide exposure can therefore provide cues to the sequence of cellular phytotoxic events (Fernández-Escalada et al. 2016; Maroli et al. 2015, 2017; Serra et al. 2015; Vivancos et al. 2011).

Advances in nanotechnology have enabled the use of nanomaterials in agriculture (Fraceto et al 2016), with nanopesticides increasingly being looked at as alternates to chemical herbicides (Ali et al. 2017; Hayles et al. 2017; Tan et al. 2018). Though they are reported to provide equal or better performance at lower doses compared with chemical herbicides (Parisi et al. 2015), their effects on crop plants are still poorly understood (Zhao et al. $2017 \mathrm{a}, 2017 \mathrm{~b}, 2017 \mathrm{c})$. A series of metabolomics and transcriptomics studies conducted to assess the metabolic response of crop plants such as cucumber (Cucumis sativus L.) (Zhao et al. 2017a), maize (Zhao et al. 2017b), and spinach (Spinacia oleracea L.) (Zhao et al. 2017c) to $\mathrm{Cu}(\mathrm{OH})_{2}$ nanopesticide exposure concluded that the nanopesticide induced significant alterations in the metabolite profiles of all the plants. In spinach, significant reductions in antioxidant- and defense-associated metabolites were reported, while in maize, $\mathrm{Cu}(\mathrm{OH})_{2}$ nanopesticide significantly decreased leaf chlorophyll content and biomass but induced an increase in the potassium and phosphorus levels and phenolic acid precursors. In contrast, foliar exposure of cucumber plants to a relatively lower dose of the nanopesticide induced activation and upregulation in mRNA levels of antioxidant and detoxification-related genes. Such studies bring into prominence the reliability of omics platforms to help us understand cropenvironment interactions at a much finer level.

Metabolomics can robustly provide instantaneous information about metabolite concentrations by measuring the static metabolite-pool levels directly. However, as metabolic processes are interconnected and dynamic, with rapid turnover rates, characterization of metabolic networks requires quantitative knowledge of intracellular fluxes (Fernie and Morgan 2013). Quantitation of metabolic fluxes through each reaction within a network can only be estimated indirectly with the help of isotopically labeled metabolic tracers (Gaudin et al. 2014; Gleixner et al 1998; Sauer 2006). Fluxomics studies such as stable isotoperesolved metabolomics (SIRM) are emerging as powerful strategies used to measure fluxes in complex interconnected metabolic networks (Kikuchi et al. 2004; Maroli et al. 2016; Srivastava et al. 2016). In weed science, only a couple of studies have used fluxbased omics studies to examine competitive physiology (Maroli et al. 2016; Miyagi et al. 2011). SIRM experiments performed using stable isotope-labeled metabolic precursors (tracers) would be the most ideal approach to study metabolic fluxes in weeds. In these experiments, the growth media can be supplemented with labeled nutrients that can then be tracked throughout the metabolic network as part of endogenous metabolism (Gaudin et al. 2014; Maroli et al. 2016). Flux rates can then be indirectly estimated from metabolite changes and isotope distribution in a network. For example, accumulation of amino acids following glyphosate application is commonly observed in glyphosatesusceptible plants (Fernández-Escalada et al. 2016; Maroli et al. 2015; Vivancos et al. 2011). Independent studies conducted by Maroli et al. (2015) and Fernández-Escalada et al. (2016) have reported that glyphosate-susceptible $A$. palmeri biotypes accumulate higher concentrations of amino acids than resistant biotypes. It is generally accepted that the higher accumulation of 
Targeted metabolomics

Polar metabolites Non-polar metabolites

\begin{abstract}
GC-MS
\end{abstract}
GC-MS LC-MS/MS

LC-MS/MS

B

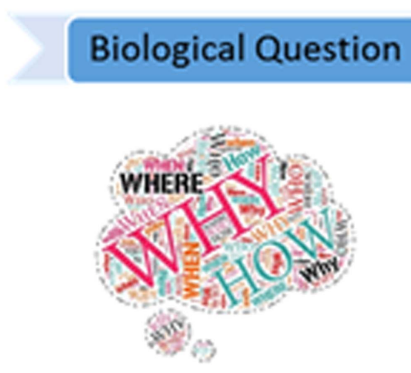

Chromatography

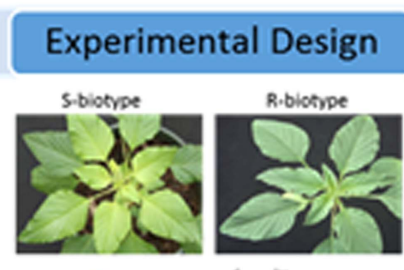

$83 x_{0} x^{\circ}$
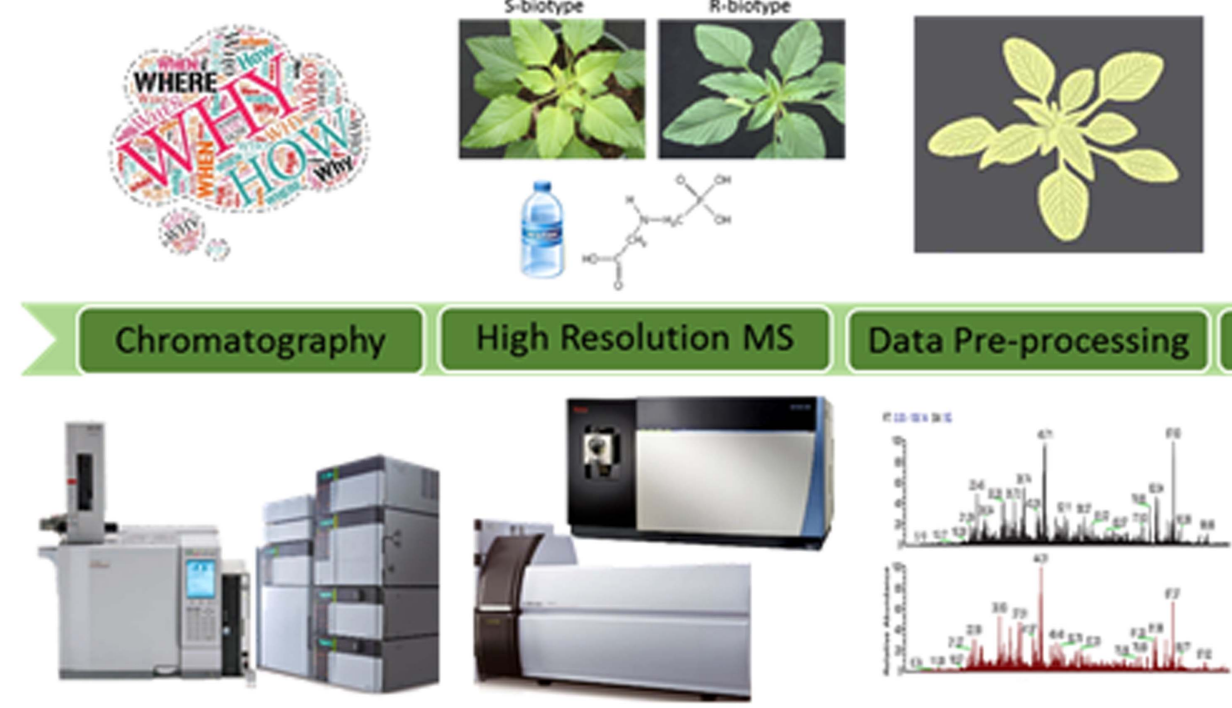

HILIC-LC-MS/MS

Polar metabolites Non-polar metabolites

Non-targeted metabolomics

C18-LC-MS/MS 
amino acids following glyphosate treatment is due to proteolysis. However, using SIRM analysis, Maroli et al. (2016) essentially described the underlying cause of higher amino acid accumulation in the susceptible biotype. It was shown that glyphosateinduced amino acid accumulation in susceptible A. palmeri biotypes is a consequence of proteolysis (catabolism) coupled with de novo synthesis of certain amino acids. In contrast, amino acid concentrations in the glyphosate-resistant biotype were predominantly due to de novo synthesis (anabolism). Thus, it can be seen from this study that the use of modern omics platforms has helped to establish the connection between metabolome and metabolic pool dynamics to elucidate the link between the glyphosate MOA and de novo amino acid synthesis.

\section{Integrated Omics Approaches to Understanding Phytotoxin MOA}

Herbicides with new MOAs are desperately needed to combat evolved and evolving herbicide resistance (Duke and Heap 2017), and no new commercial herbicides with a clearly new MOA have been commercialized since the 4-hydroxphenylpyruvate dioxygenase inhibitors in the 1980s (Duke 2012). Thus, discovery of herbicides with new MOAs is of prime importance in herbicide discovery efforts. Evidence from the natural phytotoxin literature suggests that there are many more viable MOAs than the current 20 MOAs of commercial herbicides (Dayan and Duke 2014). However, determination of the MOA of phytotoxins is not a trivial pursuit, because what we observe after herbicide treatment of a plant is the manifestation of many secondary and tertiary effects resulting from an effect on the primary target site. The literature is full of papers confusing secondary and tertiary effects with primary effects. Many of the older herbicides were commercialized before their MOAs were known, partly because the target sites were not easy to determine, due to the difficulty in working back from physiological effects to a molecular target site.

With the advent of omics technologies, new strategies for MOA determination have been devised (Duke et al. 2013; Grossmann et al. 2012a). Omics-based MOA discovery consists of building a database of any one of the different omics responses to herbicides with known MOAs and then comparing the response profile of a phytotoxin with an unknown MOA to profiles generated by phytotoxins with known MOAs. To our knowledge, this has been done in industry with only one omics method-metabolomics. This approach can be highly effective if the new compound happens to have an MOA that is in the database of omics responses to compounds with known MOAs. If not, the approach will indicate that the compound has a new MOA not represented in the database. Most companies involved in herbicide discovery have tried this approach, but only BASF has published a detailed description of how it has used omics methods to identify MOAs (Grossman et al. 2012a, 2012b). In that case, it combined both metabolomic and physionomic methods to build extensive databases of omics responses to phytotoxins with known MOAs against which to evaluate data from compounds of unknown MOAs. While a growing number of omics technologies are available to choose from, some of them being quite narrow (for example, lipidomics and glycomics), the scope of this segment will be limited to transcriptomics, proteomics, metabolomics, physionomics, and combined approaches.

Most MOA transcriptomics has been done with Arabidopsis. Transcription responses to several herbicides with known MOAs have been published (Table 2). However, a major problem with this method of determination is that at doses of the toxicant that have even a sublethal effect on the plant (for example, the dose that reduces growth by $50 \%$ ), expression of many genes is affected within a short time after treatment. Many of the affected genes are those involved in stress responses and metabolic detoxification and other means of dealing with xenobiotics. For example, Baerson et al. (2005) found that the phytotoxic allelochemical benzoxazolin-2 $(3 \mathrm{H})$-one $(\mathrm{BOA})$ upregulated many Arabidopsis genes involved in metabolism of xenobiotics and cell rescue and defense within $24 \mathrm{~h}$ after treatment. An extreme example is that of cantharidin, a potent natural phytotoxin that significantly affected gene expression of more than $6 \%$ of the genes of Arabidopsis within $2 \mathrm{~h}$ of treatment with a dose that reduced growth by $30 \%$ (Bajsa et al. 2011a, 2011b). Eventually, 10\% of the genome was affected. This is not a surprise, as cantharidin and the herbicide chemical analogue endothall both inhibit all of the serine/threonine protein phosphatases (Arabidopsis has more than 20) in plants (Bajsa et al. 2011a, 2012). These enzymes are heavily involved in signaling pathways and gene expression.

Proteomics has been used considerably less than transcriptomics to probe the MOAs or mechanisms of resistance to herbicides. Zhang and Reichers (2008) reviewed the use of proteomics in weed science research. The effects of paraquat, diuron, and norflurazon on Chlamydomonas reinhardtii were studied with proteomics (Nestler et al. 2012). Although the abundance of the target protein of norflurazon, phytoene desaturase, was unaffected, the amounts of other enzymes of the plastidic terpene pathway were affected. Diuron increased the amount of its target, the D1 protein of photosystem II, whereas some other proteins involved in photosynthetic electron transport decreased. The effects of the auxinic herbicides dicamba and clopyralid on the proteome of soybean [Glycine max (L.) Merr.] were examined by Kelley et al. (2006). They found four proteins to be strongly affected, and one of them was the product of the $\mathrm{GH} 3$ gene, a gene that they found to be strongly upregulated at the transcriptional level. Kumari et al. (2009) found that butachlor reduced levels of proteins involved in photosynthesis and respiration of the alga Aulosira fertilissima. Because the MOA of butachlor is inhibition of very long chain lipid synthesis, these effects are secondary or tertiary. Likewise, amiprophos-methyl, a herbicide that affects microtubule function, had effects on proteins associated with diverse physiological and biochemical processes but not directly associated with tubulin (Wang et al. 2011). More recently, the natural phytotoxin $\alpha$-terthienyl was found to affect 16 proteins associated with energy transduction, of which the transketolase protein was greatly reduced (Zhao et al. 2018). A transketolasealtered mutant was less sensitive to the phytotoxin, and the enzyme from the mutant was less inhibited by the compound. But the weak effect of the toxin on the enzyme is not what one would expect for a primary target site.

Studies using natural phytotoxins with unknown target sites have revealed distinct metabolic effects but no clear indication of a molecular target (Cantrell et al. 2007; Duke et al. 2011). Other metabolomic studies of phytotoxin MOAs are discussed in Duke et al. (2013). One of the more complete studies of this type was that of Trenkamp et al. (2009), who examined the effects of glufosinate, glyphosate, sulcotrione, foramsulfuron, benfuresate, and an experimental herbicide on the metabolome of Arabidopsis. Results matched the MOA for some but not all of the phytotoxins. More systematic approaches that rely on metabolic profiles of an array of phytotoxin MOAs have been more 
successful (Grossmann et al. 2010, 2012a, 2012b). Perhaps the only new phytotoxin MOAs discovered by omics methods are the determination that cinmethylin's target site is tyrosine aminotransferase (Grossmann et al. 2012b) and that of a phenylalanine analogue (PHE1) is IAA synthesis (Grossmann et al. 2012a), although in the latter case the specific enzyme target to the IAA synthesis pathway was not determined. In both cases, physionomic and metabolomic databases were used to narrow the search for the target sites. Verification of the omics indications were followed by physiological and biochemical studies.

\section{Limitations, Conclusions, and Future Directions}

Relying on orthologous genomes to annotate related genomes of weedy species has pitfalls associated with proposing biological interactions and processes based on spurious assumptions that homologous genes have conserved functionality across species (Doğramacı et al. 2015). Similarly, assembling a quality de novo reference transcriptome for weeds can be computationally difficult, due to complex gene families and high levels of heterozygosity that often occur in weeds. Polyploidy further complicates reference transcriptome assembly, although the assembly can be completed and yield insight into evolution of polyploidy in weeds (Chen et al. 2016). This becomes more critical when studying herbicide resistance, because RNA-Seq will detect all differences in gene expression and sequence; therefore, using highly unrelated resistant and susceptible populations will result in a large number of false positives (genes with significant DE that are completely unrelated to herbicide resistance). Hence, not all resistance mechanisms can be detected using RNA-Seq. Therefore, for a successful RNA-Seq experiment in non-model species such as weeds, ideally, a high-quality reference transcriptome is desired for identifying and quantifying DE genes or sequence variations. Additionally, the quality of the de novo reference transcriptome is also important, as genes will only be identified for DE and/or sequence variation if they are present in the reference assembly. In contrast, the major challenge for developing an effective highthroughput metabolomics platform lies in the chemical complexity, heterogeneity, and dynamic range of the metabolites and the challenges in developing a single extraction procedure for all metabolites. Plant extracts have a complicated biochemical composition and require extensive extraction and separation procedures to achieve reproducible results. Furthermore, very few of these metabolites can act as distinct biomarkers for a particular herbicide or phytotoxin MOA. Exceptions are EPSPS, PPO, and ceramide synthase, which cause dramatic increases in the pools of shikimic acid (Duke et al. 2003), protoporphyrin IX (Dayan and Duke 2003), and sphingoid bases (Abbas et al. 2002), respectively. Unfortunately, most other metabolites or phytotoxins do not have such dramatic effects.

As no single omics method is likely to reveal the MOA of a herbicide or natural phytotoxin, omics approaches to probe MOAs, though powerful, have to be used with caution. Several factors can influence the outcome of an omics experiment. First, physiological effects and responses are dose dependent, such that at high doses, results might be confounded by secondary targets, while at low doses, a plant might compensate too rapidly to observe anything meaningful. Second, the results are highly dependent on exposure time, wherein responses can be rapid, gradual, or delayed or sometimes may even reverse over time. Third, omics responses can vary between plant tissues and cell types, such that important effects in some cells could be masked when the entire tissue or organ is extracted. Finally, metabolicpool sizes can be deceiving, as the pool size is determined by both input and output of the pool. In many cases, changes in pool fluxes would be much more informative about the effect of a herbicide than the pool size. Moreover, even when omics methods suggest a molecular target site, it must be verified by physiological and biochemical methods. For example, histone deacetylase was found to be the target site of a phytotoxic metabolic product of $\mathrm{BOA}$, and its MOA was further probed by transcriptome analysis (Venturelli et al. 2015). It is evident that the transcriptome data would have been very unlikely to reveal the molecular target site.

Another caveat involving omics studies is that all herbicides and phytotoxins cause stress, including oxidative stress, so omics methods can be misleading to the naïve researcher. For example, Ahsan et al. (2008) found both paraquat and glyphosate to enhance the amount of proteins involved in defense against oxidative stress in leaves of glyphosate-susceptible rice (Oryza sativa L.). They concluded that this was an "alternative" effect, rather than a secondary or tertiary effect of herbicide-induced stress. Clearly, the approximately 50-fold level of resistance of crops made resistant to glyphosate by means of a glyphosateresistant EPSPS (Nandula et al. 2007) is proof that there is no alternate primary effect of glyphosate. Comparing results with different omics approaches is rare, but quite different effects have been reported with different omics approaches. For example, in the same experiment in which cantharidin's effects on the transcriptome were determined (Bajsa et al. 2011a, 2011b), samples were taken for proteome studies (Bajsa et al. 2015). A remarkable lack of correlation between transcriptome and proteome results was observed, although the lack of correspondence between transcriptome and proteome data could be due to multiple factors (Duke et al. 2013; Narayanan and Van de Ven 2014; Payne 2015). Similarly, Zhao et al. (2018) found decreases in the transketolase protein of Arabidopsis treated with $\alpha$-terthienyl, but the gene for this enzyme was upregulated by the same treatment. They hypothesized that the decrease in protein was due to direct interaction with $\alpha$-terthienyl, which resulted in upregulation of the gene to compensate.

The disconnect between comparing individual omics platforms to understand weed genetics, diversity, heterozygosity, and importantly, evolution of herbicide resistance in weeds, especially non-target site resistance, highlights the need to develop an integrated omics platform. As an example of developing blueprints for constructing low-cost genomic assemblies in weed species, Horvath et al. (2018) have sequenced gene space and transcriptome assemblies of E. esula that were used to identify promoter sequences, high-quality markers, and repetitive elements. Based on this framework, a reliable sequence for $>90 \%$ of the expressed E. esula protein-coding genes was made available. Compared with conventional screening techniques, developing herbicides with new MOAs and chemistries or evaluating natural products for use as bioherbicides can be achieved at a much faster rate using next-generation omics. Despite requiring a cautionary approach, integrated systems biology can revolutionize weed management practices by providing hitherto unknown biological information (Han et al. 2017; Kraehmer 2012). A holistic line of action with multidisciplinary integrated approaches and collaboration between weed scientist, extension specialist, and farmers is required to allow for the development of long-term, weed management strategies. Though information on candidate genes is lacking for most weed species, global gene expression profiling 
techniques, such as microarrays, can serve as effective tools for understanding NTSR mechanisms (Peng et al. 2010), while RNASeq and whole-metabolome profiling can identify genes and metabolites involved in regulating biochemical processes in a weed. An outcome of a systems biology approach is the ambitious RNAi technology (BioDirect ${ }^{\mathrm{TM}}$ ) developed by Monsanto to exploit precise RNA segments coding for EPSPS protein in reversing glyphosate resistance in weeds (Hollomon 2012; Shaner and Beckie 2014). In conclusion, it can be said that genomics, transcriptomics, and other methods for high-throughput screening can yield promising results for elucidating basic weed biology concepts as well as insights into the response of weeds to biotic and abiotic stresses and crop-weed competition. Thus, with the aid of these omics platforms, improved knowledge of weed biology, genetics, and physiology can be gained quickly, paving the way for the development of long-term, sustainable weed management practices.

Acknowledgements. The authors would like to thank the WSSA for providing the funding and platform to organize this symposium at the 55th Annual Meeting of the Weed Science Society of America, Lexington, KY. The authors would also like to acknowledge Amy Lawton-Rauh and Patrick Tranel for their contributions to the symposium. No conflicts of interest have been declared.

\section{References}

Abbas HK, Duke SO, Sheir WT, Duke MV (2002) Inhibition of ceramide synthesis in plants by phytotoxins. Pages 211-219 in Upadhyay RK, ed. Advances in Microbial Toxin Research and Its Biochemical Exploitation. London: Kluwer Academic/Plenum

Agrawal GK, Jwa N, Lebrun M, Job D, Rakwal R (2010) Plant secretome: unlocking secrets of the secreted proteins. Proteomics 10:799-827

Ahsan N, Lee D-G, Lee K-W, Alam I, Lee S-H, Bahk JD, Lee B-H (2008) Glyphosate-induced oxidative stress in rice leaves revealed by proteomic approach. Plant Physiol Biochem 46:1062-1070

Ali M, Nair KK, Kumar R, Gopal M, Srivastava C, Siddiqi WA (2017) Development and evaluation of chitosan-sodium alginate based etofenprox as nanopesticide. Adv Sci Eng Med 9:137-143

Aliferis KA, Chrysayi-Tokousbalides M (2006) Metabonomic strategy for the investigation of the mode of action of the phytotoxin ( $5 \mathrm{~S}, 8 \mathrm{R}, 13 \mathrm{~S}, 16 \mathrm{R})$ (-)-pyrenophorol using $1 \mathrm{H}$ nuclear magnetic resonance fingerprinting. J Agric Food Chem 54:1687-1692

Aliferis KA, Chrysayi-Tokousbalides M (2011) Metabolomics in pesticide research and development: review and future perspectives. Metabolomics 7:35-53

Aliferis KA, Jabaji S (2011) Metabolomics-a robust bioanalytical approach for the discovery of the modes-of-action of pesticides: a review. Pestic Biochem Physiol 100:105-117

Amigo-Benavent M, Clemente A, Caira S, Stiuso P, Ferranti P, Castillo MD (2014) Use of phytochemomics to evaluate the bioavailability and bioactivity of antioxidant peptides of soybean $\beta$-conglycinin. Electrophoresis 35:1582-1589

An J, Shen X, Ma Q, Yang C, Liu S, Chen Y (2014) Transcriptome profiling to discover putative genes associated with paraquat resistance in goosegrass (Eleusine indica L.). PLoS ONE 9:e99940

Anderson JV (2008) Emerging technologies: an opportunity for weed biology research. Weed Sci 56:281-282

Anderson JV, Delseny M, Fregene MA, Jorge V, Mba C, Lopez C, Restrepo S, Soto M, Piegu B, Verdier V, Cooke R (2004) An EST resource for cassava and other species of Euphorbiaceae. Plant Mol Biol 56:527-539

Anderson JV, Gesch RW, Jia Y, Chao WS, Horvath DP (2005) Seasonal shifts in dormancy status, carbohydrate metabolism, and related gene expression in crown buds of leafy spurge. Plant Cell Environ 28:1567-1578

Anderson JV, Horvath DP (2001) Random sequencing of cDNAs and identification of mRNAs. Weed Sci 49:590-597
Anderson JV, Horvath DP, Chao WS, Foley ME, Hernandez AG, Thimmapuram J, Liu L, Gong GL, Band M, Kim R, Mikel MA (2007) Characterization of an EST database for the perennial weed leafy spurge: an important resource for weed biology research. Weed Sci 55:193-203

Arabidopsis Genome Initiative (2000) Analysis of the genome sequence of the flowering plant Arabidopsis thaliana. Nature 408:796-815

Araníbar N, Singh BK, Stockton GW, Ott KH (2001) Automated mode-ofaction detection by metabolic profiling. Biochem Biophys Res Commun 286:150-155

Baerson SR, Sánchez-Moreiras A, Pedrol-Bonjoch N, Schulz M, Kagan IA, Agarwal AL, Reigosa MJ, Duke SO (2005) Detoxification and transcriptome response in Arabidopsis seedlings exposed to the allelochemical benzoxazolin-2(3H)-one (BOA). J Biol Chem 280:21867-21881

Bajsa J, Pan Z, Dayan FE, Owens DK, Duke SO (2012) Validation of serine/ threonine protein phosphatase as the herbicide target site of endothall. Pestic Biochem Physiol 102:38-44

Bajsa J, Pan Z, Duke SO (2011a) Serine/threonine protein phosphatases: Multi-purpose enzymes in control of defense mechanisms. Plant Signal Behav 6:1921-1925

Bajsa J, Pan Z, Duke SO (2011b) Transcriptional responses to cantharidin, a protein phosphatase inhibitor. in, Arabidopsis thaliana reveal the involvement of multiple signal transduction pathways. Physiol Plantarum 143:188-205

Bajsa J, Pan Z, Duke SO (2015) Cantharidin, a protein phosphatase inhibitor with broad effects on the transcriptome, strongly upregulates glutathione-Stransferase in the Arabidopsis proteome. J Plant Physiol 173:33-40

Basu C, Halfhill MD, Mueller TC, Stewart CN (2004) Weed genomics: new tools to understand weed biology. Trend Plant Sci 9:391-398

Beckwith EJ, Yanovsky MJ (2014) Circadian regulation of gene expression: at the crossroads of transcriptional and post-transcriptional regulatory networks. Curr Opin Genet Dev 27:35-42

Bell CJ, Dixon RA, Farmer AD, Flores R, Inman J, Gonzales RA, Harrison MJ, Paiva NL, Scott AD, Weller JW, May GD (2001) The Medicago Genome Initiative: a model legume database. Nucleic Acids Res 29:114-117

Belz RG, Duke SO (2014) Herbicides and plant hormesis. Pest Manag Sci 70:698-707

Bevan M, Walsh S (2005) The Arabidopsis genome: a foundation for plant research. Genome Res 15:1632-1642

Braun P, Aubourg S, Van Leene J, De Jaeger G, Lurin C (2013) Plant protein interactomes. Annu Rev Plant Biol 64:161-187

Brunetti AE, Neto FC, Vera MC, Taboada C, Pavarini DP, Bauermeister A, Lopes NP (2018) An integrative omics perspective for the analysis of chemical signals in ecological interactions. Chem Soc Rev 42:1574-1591

Cantrell CL, Duke SO, Fronczek FR, Osbrink WLA, Mamonov LK, Vassilyev JI, Wedge DE, Dayan FE (2007) Phytotoxic eremophilanes from Ligularia macrophylla. J Agric Food Chem 55:10656-10663

Chao WS, Horvath DP, Anderson JV, Foley ME (2005) Potential model weeds to study genomics, ecology, and physiology in the 21 st century. Weed Sci 53:929-937

Chen J, Huang H, Wei S, Huang Z, Wang X, Zhang C (2017) Investigating the mechanisms of glyphosate resistance in goosegrass (Eleusine indica (L.) Gaertn.) by RNA sequencing technology. Plant J 89:407-415

Chen S, McElroy JS, Dane F, Goertzen LR (2016) Transcriptome assembly and comparison of an allotetraploid weed species, annual bluegrass, with its two diploid progenitor species, Poa supina Schrad and Poa infirma Kunth. Plant Genome 9, 10.3835/plantgenome2015.06.0050

Chi WC, Fu SF, Huang TL, Chen YA, Chen CC, Huang HJ (2011) Identification of transcriptome profiles and signaling pathways for the allelochemical juglone in rice roots. Plant Mol Biol 77:591-607

Corbett CA, Tardif FJ (2006) Detection of resistance to acetolactate synthase inhibitors in weeds with emphasis on DNA-based techniques: a review. Pest Manag Sci 62:584-597

Cummins I, Wortley DJ, Sabbadin F, He Z, Coxon CR, Straker HE, Sellars JD, Knight K, Edwards L, Hughes D, Kaundun SS, Hutchings SJ, Steel PG, Edwards R (2013) Key role for a glutathione transferase in multipleherbicide resistance in grass weeds. Proc Natl Acad Sci USA 110: 5812-5817 
Das M, Reichman JR, Haberer G, Welzl G, Aceituno FF, Mader MT, Watrud LS, Pfleeger TG, Guiterrez RA, Schaffner AR, Olszyk DM (2010) A composite transcriptional signature differentiates responses towards closely related herbicides in Arabidopsis thaliana and Brassica napus. Plant Mol Biol 72:545-556

Dayan FE, Duke SO (2003) Herbicides: protoporphyrinogen oxidase inhibitors. Pages 850-863 in Plimmer JR, Gammon DW \& Ragsdale NN eds., Encyclopedia of Agrochemicals Volume 2. New York: Wiley

Dayan FE, Duke SO (2014) Natural compounds as next-generation herbicides. Plant Physiol 166:1090-1105

del Castillo MD, Martinez-Saez N, Amigo-Benavent M, Silvan JM (2013) Phytochemomics and other omics for permitting health claims made on foods. Food Res Int 54:1237-1249

Délye C (2013) Unravelling the genetic bases of non-target-site-based resistance (NTSR) to herbicides: a major challenge for weed science in the forthcoming decade. Pest Manag Sci 69:176-187

De Vos RCH, Moco S, Lommen A, Keurentjes JJ, Bino RJ, Hall RD (2007) Untargeted large-scale plant metabolomics using liquid chromatography coupled to mass spectrometry. Nat Protoc 2:778

Doğramacı M, Anderson JV, Chao WS, Foley ME (2014) Foliar application of glyphosate affects molecular mechanisms in underground adventitious buds of leafy spurge (Euphorbia esula) and alters their vegetative growth patterns. Weed Sci 62:217-229

Doğramacı M, Gramig GG, Anderson JV, Chao WS, Foley ME (2016) Field application of glyphosate induces molecular changes affecting vegetative growth processes in leafy spurge (Euphorbia esula). Weed Sci 64:87-100

Doğramacı M, Horvath DP, Anderson JV (2015) Meta-analysis identifies potential molecular markers for endodormancy in crown buds of leafy spurge. Pages 197-219 in Anderson JV, ed. Advances in Plant Dormancy. Cham, Switzerland: Springer International

Dorn KM, Fankhauser JD, Wyse DL, Marks MD (2015) A draft genome of field pennycress (Thlaspi arvense) provides tools for the domestication of a new winter biofuel crop. DNA Res 22:121-131

Duhoux A, Carrère S, Gouzy J, Bonin L, Délye C (2015) RNA-Seq analysis of rye-grass transcriptomic response to an herbicide inhibiting acetolactatesynthase identifies transcripts linked to non-target-site-based resistance. Plant Mol Biol 87:473-487

Duke SO (2012) Why have no new herbicide modes of action appeared in recent years? Pest Manag Sci 68:505-512

Duke SO, Baerson SR, Rimando AM (2003) Glyphosate. In Plimmer JR, Gammon DW \& Ragsdale NN eds., Encyclopedia of Agrochemicals Volume 2. New York: Wiley

Duke SO, Bajsa J, Pan Z (2013) Omics methods for probing the mode of action of natural and synthetic phytotoxins. J Chem Ecol 39:333-347

Duke SO, Evidente A, Fiore M, Rimando AM, Dayan FE, Vurro M, Christiansen N, Looser R, Hutzler J, Grossmann K (2011) Effects of the aglycone of ascaulitoxin on amino acid metabolism in Lemna paucicostata. Pestic Biochem Physiol 100:41-50

Duke SO, Heap I (2017) Evolution of weed resistance to herbicides: what have we learned after seventy years? Pages $63-86$ in Jugulam M, ed. Biology, Physiology and Molecular Biology of Weeds. Boca Raton, FL: CRC

Duke SO, Powles SB (2008) Glyphosate: a once-in-a-century herbicide. Pest Manag Sci 64:319-325

Faure D, Tannières M, Mondy S, Dessaux Y (2011) Recent contributions of metagenomics to studies on quorum-sensing and plant-pathogen interactions. Pages 253-263 in Marco D, ed. Metagenomics: Current Innovations and Future Trends. London: Caister Academic

Fernández-Escalada M, Gil-Monreal M, Zabalza A, Royuela M (2016) Characterization of the Amaranthus palmeri physiological response to glyphosate in susceptible and resistant populations. J Agric Food Chem 64:95-106

Fernández-Escalada $\mathrm{M}$, Zulet-González A, Gil-Monreal M, Zabalza A, Ravet K, Gaines T, Royuela M (2017) Effects of EPSPS copy number variation $(\mathrm{CNV})$ and glyphosate application on the aromatic and branched chain amino acid synthesis pathways in Amaranthus palmeri. Front Plant Sci 8:1970

Fernie AR, Morgan JA (2013) Analysis of metabolic flux using dynamic labelling and metabolic modelling. Plant Cell Environ 36:1738-1750
Fiehn O (2002) Metabolomics—the link between genotypes and phenotypes. Plant Mol Biol 48:155-171

Finkel E (2009) With "phenomics," plant scientists hope to shift breeding into overdrive. Science 325:380-381

Foley ME, Chao WS, Horvath DP, Doğramacı M, Anderson JV (2013) The transcriptomes of dormant leafy spurge seeds under alternating temperature are differentially affected by a germination-enhancing pretreatment. J Plant Physiol 170:539-547

Fraceto LF, Grillo R, de Medeiros GA, Scognamiglio V, Rea G, Bartolucci C (2016) Nanotechnology in agriculture: which innovation potential does it have? Front Environ Sci 4:20

Fukushima A, Kusano M, Redestig H, Arita M, Saito K (2009) Integrated omics approaches in plant systems biology. Curr Opin Chem Biol 13: 532-538

Gaines TA, Lorentz L, Figge A, Herrmann J, Maiwald F, Ott MC, Han H, Busi R, Yu Q, Powles SB, Beffa R (2014) RNA-Seq transcriptome analysis to identify genes involved in metabolism-based diclofop resistance in Lolium rigidum. Plant J 78:865-876

Gaines TA, Tranel PJ, Fleming MB, Patterson EL, Küpper A, Ravet K, Giacomini DA, Gonzalez S, Beffa R (2017) Applications of genomics in weed science. Pages 185-217 in Jugulam M, ed. Biology, Physiology and Molecular Biology of Weeds. Boca Raton, FL: CRC Press

Gaines TA, Zhang W, Wang D, Bukun B, Chisholm ST, Shaner DL, Nissen SJ, Patzoldt WL, Tranel PJ, Culpepper AS, Grey TL, Webster TM, Vencill WK, Sammons RD, Jiang J, Preston C, Leach JE, Westra P (2010) Gene amplification confers glyphosate resistance in Amaranthus palmeri. Proc Natl Acad Sci USA 107:1029-1034

Gardin JAC, Gouzy J, Carrere S, Delye C (2015) ALOMYbase, a resource to investigate non-target-site-based resistance to herbicides inhibiting acetolactate-synthase (ALS) in the major grass weed Alopecurus myosuroides (black-grass). BMC Genomics 16:590

Gaudin Z, Cerveau D, Marnet N, Bouchereau A, Delavault P, Simier P, Pouvreau JB (2014) Robust method for investigating nitrogen metabolism of $15 \mathrm{~N}$ labeled amino acids using AccQ Tag ultra performance liquid chromatography-photodiode array-electrospray ionization-mass spectrometry: application to a parasitic plant-plant interaction. Anal Chem 86:1138-1145

Giacomini DA, Gaines T, Beffa R, Tranel PJ (2018) Optimizing RNA-seq studies to investigate herbicide resistance. Pest Manag Sci, 10.1002/ps.4822

Gleixner G, Scrimgeour C, Schmidt HL, Viola R (1998) Stable isotope distribution in the major metabolites of source and sink organs of Solanum tuberosum L.: a powerful tool in the study of metabolic partitioning in intact plants. Planta 207:241-245

Golisz A, Sugano M, Fujii Y (2008) Microarray expression profiling of Arabidopsis thaliana L. in response to allelochemicals identified in buckwheat. J Exp Bot 59:3099-3109

Golisz A, Sugano M, Hiradate S, Fujii Y (2011) Microarray analysis of Arabidopsis plants in response to the allelochemical 1-DOPA. Planta 233:231-240

Großkinsky DK, Svensgaard J, Christensen S, Roitsch T (2015) Plant phenomics and the need for physiological phenotyping across scales to narrow the genotype-to-phenotype knowledge gap. J Exp Bot 66:5429-5440

Grossman K, Chistiansen N, Looser R, Tresch S, Hutzler Pollmann S, Ehrhardt T (2012aPhysionomics and metabolomics-two key approaches in herbicide mode of action discovery. Pest Manag Sci 68:294-504

Grossmann K, Hutzler J, Tresch S, Christiansen N, Looser R, Ehrhardt (2012bOn the mode of action of the herbicide cinmethylin and 5-benzyloxymethyl-1,2-isoxazolines: putative inhibitors of plant tyrosine aminotransferase. Pest Manag Sci 68:482-492

Grossmann K, Niggeweg R, Christiansen N, Looser R, Ehrhardt T (2010) The herbicide saflufenacil (Kixor ${ }^{\mathrm{TM}}$ ) is a new inhibitor of protoporphyrinogen IX oxidase activity. Weed Sci 58:1-9

Guo L, Qiu J, Ye C, Jin G, Mao L, Zhang H, Yang X, Peng Q, Wang Y, Jia L, Lin $Z$ (2017) Echinochloa crus-galli genome analysis provides insight into its adaptation and invasiveness as a weed. Nature Commun 8:1031

Haggarty J, Burgess KE (2017) Recent advances in liquid and gas chromatography methodology for extending coverage of the metabolome. Curr Opin Biotechnol 43:77-85 
Han H, Vila-Aiub MM, Jalaludin A, Yu Q, Powles SB (2017) A double EPSPS gene mutation endowing glyphosate resistance shows a remarkably high resistance cost. Plant Cell Environ 40:3031-3042

Hayles J, Johnson L, Worthley C, Losic D (2017) Nanopesticides: a review of current research and perspectives. Pages 193-225 in Grumezescu AM, ed. New Pesticides and Soil Sensors. Amsterdam, Netherlands: Elsevier

He Q, Kim KW, Park YJ (2017) Population genomics identifies the origin and signatures of selection of Korean weedy rice. Plant Biotechnol J 15:357-366

Heinzle E, Matsuda F, Miyagawa H, Wakasa K, Nishioka T (2007) Estimation of metabolic fluxes, expression levels and metabolite dynamics of a secondary metabolic pathway in potato using label pulse-feeding experiments combined with kinetic network modelling and simulation. Plant J 50:176-187

Hirai MY, Yano M, Goodenowe DB, Kanaya S, Kimura T, Awazuhara M, Arita M, Fujiwara T, Saito K (2004) Integration of transcriptomics and metabolomics for understanding of global responses to nutritional stresses in Arabidopsis thaliana. Proc Natl Acad Sci USA 101:10205-10210

Hollomon DW (2012) Do we have the tools to manage resistance in the future? Pest Manag Sci 68:149-154

Horvath DP (2010) Genomics for weed science. Curr Genomics 11:47-51

Horvath DP (2015) Dormancy-associated MADS-BOX genes: A review. Pages 137-146 in Anderson J, ed. Advances in Plant Dormancy. Cham, Switzerland: Springer

Horvath DP, Anderson JV (2002) A molecular approach to understanding root bud dormancy in leafy spurge. Weed Sci 50:227-231

Horvath DP, Anderson JV, Soto-Suárez M, Chao WS (2006) Transcriptome analysis of leafy spurge (Euphorbia esula) crown buds during shifts in welldefined phases of dormancy. Weed Sci 54:821-827

Horvath DP, Chao WS, Anderson JV (2002) Molecular analysis of signals controlling dormancy and growth in underground adventitious buds of leafy spurge. Plant Physiol 128:1439-1446

Horvath DP, Chao WS, Suttle JC, Thimmapuram J, Anderson JV (2008) Transcriptome analysis identifies novel responses and potential regulatory genes involved in seasonal dormancy transitions of leafy spurge (Euphorbia esula L.). BMC Genomics 9:536

Horvath DP, Patel S, Doğramacı M, Chao WS, Anderson JV, Foley ME, Scheffler B, Lazo G, Dorn K, Yan C, Childers A (2018) Gene space and transcriptome assemblies of leafy spurge (Euphorbia esula) identify promoter sequences, repetitive elements, high-quality markers, and a fulllength chloroplast genome. Weed Sci 66:355-367

Horvath DP, Schaffer R, West M, Wisman E (2003) Arabidopsis microarrays identify conserved and differentially expressed genes involved in shoot growth and development from distantly related plant species. Plant J 34:125-134

Jaini R, Wang P, Dudareva N, Chapple C, Morgan JA (2017) Targeted metabolomics of the phenylpropanoid pathway in Arabidopsis thaliana using reversed phase liquid chromatography coupled with tandem mass spectrometry. Phytochem Anal 28:267-276

Jorrín-Novo JV, Maldonado AM, Echevarría-Zomeño S, Valledor L, Castillejo MA, Curto M, Valero J, Sghaier B, Donoso G, Redondo I (2009) Plant proteomics update (2007-2008): second-generation proteomic techniques, an appropriate experimental design, and data analysis to fulfill MIAPE standards, increase plant proteome coverage and expand biological knowledge. J Proteomics 72:285-314

Kantar MB, Nashoba AR, Anderson JE, Blackman BK, Rieseberg LH (2017) The genetics and genomics of plant domestication. BioScience 67:971-982

Keith BK, Burns EE, Bothner B, Carey CC, Mazurie AJ, Hilmer JK, Biyiklioglu S, Budak H, Dyer WE (2017) Intensive herbicide use has selected for constitutively elevated levels of stress-responsive mRNAs and proteins in multiple herbicide-resistant Avena fatua L. Pest Manag Sci 73:22672281

Kelly KB, Zhang Q, Lambert KN, Riechers DE (2006) Evaluation of auxinresponsive genes in soybean for detection of off-target growth regulator herbicides. Weed Sci 54:220-229

Kikuchi J, Shinozaki K, Hirayama T (2004) Stable isotope labeling of Arabidopsis thaliana for an NMR-based metabolomics approach. Plant Cell Physiol 45:1099-1104

Kitano H (2002) Systems biology: a brief overview. Science 295:1662-1664
Kohler C, Springer N (2017) Plant epigenomics—deciphering the mechanisms of epigenetic inheritance and plasticity in plants. Genome Biol 18:132

Kraehmer H (2012) Innovation: changing trends in herbicide discovery. Outlooks Pest Manag 23:115-118

Kreiner JM, Stinchcombe JR, Wright SI (2018) Population genomics of herbicide resistance: adaptation via evolutionary rescue. Ann Rev Plant Biol 69, 10.1146/annurev-arplant-042817-040038

Kumar S, Kumar K, Pandey P, Rajamani V, Padmalatha KV, Dhandapani G, Kanakachari M, Leelavathi S, Kumar PA, Reddy VS (2013) Glycoproteome of elongating cotton fiber cells. Mol Cell Proteomics 12:3677-3689

Kumari N, Narayan OM, Rai LC (2009) Understanding butachlor toxicity in Aulosira fertilissima using physiological, biochemical and proteomic approaches. Chemsophere 77:1501-1507

Lechelt-Kunze C, Sans-Piché F, Riedl J, Altenburger R, Haertig C, Laue G, Smitt-Jansen M (2003) Flufenacet herbicide treatment phenocopies the fiddlehead mutant in Arabidopsis thaliana. Pest Manag Sci 59:847-856

LeClere S, Wu C, Westra P, Sammons RD (2018) Cross-resistance to dicamba, 2,4-D, and fluroxypyr in Kochia scoparia is endowed by a mutation in an AUX/IAA gene. Proc Natl Acad Sci USA, 10.1073/pnas.1712372115

Lee RM, Tranel PJ (2008) Utilization of DNA microarrays in weed science research. Weed Sci 56:283-289

Leslie T, Baucom RS (2014) De novo assembly and annotation of the transcriptome of the agricultural weed Ipomoea purpurea uncovers gene expression changes associated with herbicide resistance. G3-Genes Genomes Genetics 4:2035-2047

Liberman LM, Sozzani R, Benfey PN (2012) Integrative systems biology: an attempt to describe a simple weed. Curr Opin Plant Biol 15:162-167

Manabe Y, Tinker N, Colville A, Miki B (2007) CSR1, the sole target of imidazolinone herbicide in Arabidopsis thaliana. Plant Cell Physiol 48:1340-1358

Maroli AS, Nandula VK, Dayan FE, Duke SO, Gerard P, Tharayil N (2015) Metabolic profiling and enzyme analyses indicate a potential role of antioxidant systems in complementing glyphosate resistance in an Amaranthus palmeri biotype. J Agric Food Chem 63:9199-9209

Maroli AS, Nandula VK, Duke SO, Gerard P, Tharayil N (2017) Comparative metabolomic analyses of Ipomoea lacunosa biotypes with contrasting glyphosate tolerance captures herbicide-induced differential perturbations in cellular physiology. J Agric Food Chem 66:2027-2039

Maroli AS, Nandula VK, Duke SO, Tharayil N (2016) Stable isotope resolved metabolomics reveals the role of anabolic and catabolic processes in glyphosate-induced amino acid accumulation in Amaranthus palmeri biotypes. J Agric Food Chem 64:7040-7048

Matzrafi M, Shaar-Moshe L, Rubin B, Peleg Z (2017) Unraveling the transcriptional basis of temperature-dependent pinoxaden resistance in Brachypodium hybridum. Front Plant Sci 8:1064

Maxwell BD, Foley ME, Fay PK (1987) The influence of glyphosate on bud dormancy in leafy spurge (Euphorbia esula). Weed Sci 35:6-10

McElroy JS (2018) Weed Genomic Data Repository. http://weedgenomics.org/ species. Accessed: April 12, 2018

Miyagi A, Takahara K, Kasajima I, Takahashi H, Kawai-Yamada M, Uchimiya $\mathrm{H}$ (2011) Fate of ${ }^{13} \mathrm{C}$ in metabolic pathways and effects of high $\mathrm{CO}_{2}$ on the alteration of metabolites in Rumex obtusifolius L. Metabolomics 7:524-535

Miyagi A, Takahara K, Takahashi H, Kawai-Yamada M, Uchimiya H (2010) Targeted metabolomics in an intrusive weed, Rumex obtusifolius L., grown under different environmental conditions reveals alterations of organ related metabolite pathway. Metabolomics 6:497-510

Moghe GD, Hufnagel DE, Tang H, Xiao Y, Dworkin I, Town CD, Conner JK, Shiu SH (2014) Consequences of whole-genome triplication as revealed by comparative genomic analyses of the wild radish Raphanus raphanistrum and three other Brassicaceae species. Plant Cell 26:1925-1937

Molin WT, Wright AA, Lawton-Rauh A, Saski CA (2017) The unique genomic landscape surrounding the EPSPS gene in glyphosate resistant Amaranthus palmeri: a repetitive path to resistance. BMC Genomics 18:91

Morsy M, Gouthu S, Orchard S, Thorneycroft D, Harper JF, Mittler R, Cushman JC (2008) Charting plant interactomes: possibilities and challenges. Trends Plant Sci 13:183-191

Nandula VK, Reddy KN, Koger CH, Poston DH, Rimando AM, Duke SO, Bond JA, Ribeiro DN (2012) Multiple resistance to glyphosate and 
pyrithiobac in Palmer amaranth (Amaranthus palmeri) from Mississippi and response to flumiclorac. Weed Sci 60:179-188

Nandula VK, Reddy KN, Rimando AM, Duke SO, Poston DH (2007) Glyphosate-resistant and -susceptible soybean (Glycine max) and canola (Brassica napus) dose response and metabolism relationships with glyphosate. J Agric Food Chem 55:3540-3545

Narayanan R, Van de Ven WJM (2014) Transcriptome and proteome analysis: a perspective on correlation. MOJ Proteomics Bioinform 1:00027

Narayanan S, Tamura PJ, Roth MR, Prasad PVV, Welti R (2016) Wheat leaf lipids during heat stress: I. high day and night temperatures result in major lipid alterations. Plant Cell Environ 39:787-803

Nelson R, Wiesner-Hanks T, Wisser R, Balint-Kurti P (2018) Navigating complexity to breed disease-resistant crops. Nat Rev Genet 19:21-33

Nestler H, Groh KJ, Schönenberger R, Eggen RIL, Suter MJ-F (2012) Linking proteome responses with physiological and biochemical effects of herbicide-exposed Chlamydomonas reinhardii. J Proteome 75:5370-5385

Niittylae T, Chaudhuri B, Sauer U, Frommer WB (2009) Comparison of quantitative metabolite imaging tools and carbon-13 techniques for fluxomics. Pages 355-372 in Belostotsky D, ed. Plant Systems Biology. Methods in Molecular Biology (Methods and Protocols) Volume 553. New York: Humana

Nuhse TS, Stensballe A, Jensen ON, Peck SC (2004) Phosphoproteomics of the Arabidopsis plasma membrane and a new phosphorylation site database. Plant Cell 16:2394-2405

Olsen KM, Caicedo AL, Jia Y (2007) Evolutionary genomics of weedy rice in the USA. J Integr Plant Biol 49:811-816

Palsson B (2002) In silico biology through "omics". Nat Biotechnol 20:649-650

Parisi C, Vigani M, Rodríguez-Cerezo E (2015) Agricultural nanotechnologies: what are the current possibilities? Nano Today 10:124-127

Pasquer F, Ochsner U, Zarn J, Keller B (2006) Common and distinct gene expression patterns induced by the herbicides 2,4-dichlorophenoxyacetic acid, cinidon-ethyl and tribenuron-methyl in wheat. Pest Manag Sci 62:1155-1167

Payne SH (2015) The utility of protein and mRNA correlation. Trends Biochem Sci 40:1-3

Pedersen HL, Fangel JU, McCleary B, Ruzanski C, Rydahl MG, Ralet M, Farkas V, von Schantz L, Marcus SE, Andersen MCF, Field R, Ohlin M, Knox JP, Clausen MH, Willats WGT (2012) Versatile high resolution oligosaccharide microarrays for plant glycobiology and cell wall research. J Biol Chem 287:39429-39438

Peng Y, Abercrombie LLG, Yuan JS, Riggins CW, Sammons RD, Tranel PJ, Stewart CN (2010) Characterization of the horseweed (Conyza canadensis) transcriptome using GS-FLX 454 pyrosequencing and its application for expression analysis of candidate non-target herbicide resistance genes. Pest Manag Sci 66:1053-1062

Peng Y, Lai Z, Lane T, Nageswara-Rao M, Okada M, Jasieniuk M, O'Geen H, Kim RW, Sammons RD, Rieseberg LH, Stewart CN (2014) De novo genome assembly of the economically important weed horseweed using integrated data from multiple sequencing platforms. Plant Physiol 166:1241-1254

Perazzolli M, Palmieri MC, Matafora V, Bachi A, Pertot I (2016) Phosphoproteomic analysis of induced resistance reveals activation of signal transduction processes by beneficial and pathogenic interaction in grapevine. J Plant Physiol 195:59-72

Pérez-Alonso MM, Carrasco-Loba V, Medina J, Vicente-Carbajosa J, Pollmann S (2018) When transcriptomics and metabolomics work hand in hand: a case study characterizing plant CDF transcription factors. High Throughput 7:7

Raghavan V, Ong EK, Dalling MJ, Stevenson TW (2006) Regulation of genes associated with auxin, ethylene and ABA pathways by 2,4-dichlorophenoxyacetic acids in Arabidopsis. Funct Integr Genom 6:60-70

Ravet K, Patterson E, Krähmer H, Hamouzová K, Fan L, Jasieniuk M, LawtonRauh A, Malone J, McElroy JS, Merotto A, Westra P, Preston C, Vila-Aiub M, Busi R, Tranel P, Reinhardt C, Saski C, Beffa R, Neve P, Gaines T (2018) The power and potential of genomics in weed biology and management. Pest Manag Sci, 10.1002/ps.5048

Riggins CW, Peng YH, Stewart CN, Tranel PJ (2010) Characterization of de novo transcriptome for waterhemp (Amaranthus tuberculatus) using GS-
FLX 454 pyrosequencing and its application for studies of herbicide targetsite genes. Pest Manag Sci 66:1042-1052

Rochfort S (2005) Metabolomics reviewed: a new "omics" platform technology for systems biology and implications for natural products research. J Nat Prod 68:1813-1820

Roossinck MJ (2015) Metagenomics of plant and fungal viruses reveals an abundance of persistent lifestyles. Front Microbiol 5:767

Sauer U (2006) Metabolic networks in motion: 13C-based flux analysis. Mol Syst Biol 2:62

Schena M, Shalon D, Davis RW, Brown PO (1995) Quantitative monitoring of gene expression patterns with a complementary DNA microarray. Science 270:467-470

Serra AA, Couée I, Renault D, Gouesbet G, Sulmon C (2015) Metabolic profiling of Lolium perenne shows functional integration of metabolic responses to diverse subtoxic conditions of chemical stress. J Exp Bot 66:1801-1816

Shaner DL, Beckie HJ (2014) The future for weed control and technology. Pest Manag Sci 70:1329-1339

Srivastava A, Kowalski GM, Callahan DL, Meikle PJ, Creek DJ (2016) Strategies for extending metabolomics studies with stable isotope labelling and fluxomics. Metabolites 6:32

Stewart CN Jr, ed (2009) Weedy and Invasive Plant Genomics. Hoboken, NJ: Wiley. $253 \mathrm{p}$

Stewart CN Jr, Tranel PJ, Horvath DP, Anderson JV, Rieseberg LH, Westwood JH, Mallory-Smith CA, Zapiola ML, Dlugosch KM (2009) Evolution of weediness and invasiveness: charting the course for weed genomics. Weed Sci 57:451-462

Stewart CN Jr, Yanhui P, Abercrombie LG, Halfhill MD, Rao MR, Ranjan P, Hu J, Sammons RD, Heck GR, Tranel PJ, Yuan JS (2010) Genomics of glyphosate resistance. Pages 149-165 in Nandula VK, ed. Glyphosate Resistance in Crops and Weeds: History, Development and Management. Hoboken, NJ: Wiley

Sumner LW, Lei Z, Nikolau BJ, Saito K (2015) Modern plant metabolomics: advanced natural product gene discoveries, improved technologies, and future prospects. Nat Prod Rep 32:212-229

Szechyńska-Hebda M, Budiak P, Gawroński P, Górecka M, Kulasek M, Karpiński S (2015) Plant physiomics: photoelectrochemical and molecular retrograde signalling in plant acclimatory and defence responses. Pages 439-457 in Barh D, Khan M \& Davies E eds., PlantOmics: The Omics of Plant Science. New Delhi: Springer

Tan W, Gao Q, Deng C, Wang Y, Lee WY, Hernandez-Viezcas JA, PeraltaVidea JR, Gardea-Torresdey JL (2018) Foliar exposure of $\mathrm{Cu}(\mathrm{OH})_{2}$ nanopesticide to basil (Ocimum basilicum): variety-dependent copper translocation and biochemical responses. J Agric Food Chem 66:33583366

Tanveer T, Shaheen K, Parveen S, Kazi AG, Ahmad P (2014) Plant secretomics: identification, isolation, and biological significance under environmental stress. Plant Signal Behav 9:e29426

Thaysen-Andersen M, Packer NH (2014) Advances in LC-MS/MS-based glycoproteomics: getting closer to system-wide site-specific mapping of the $\mathrm{N}$ - and $\mathrm{O}$-glycoproteome. Biochim Biophys Acta 1844:1437-1452

Tranel PJ, Horvath DP (2009) Molecular biology and genomics: new tools for weed science. BioScience 59:207-215

Trenkamp S, Eckes P, Busch M, Fernie AR (2009) Temporarily resolved GCMS-based metabolic profiling of herbicide treated plants reveals that changes in polar primary metabolites alone can distinguish herbicides of differing modes of action. Metabolomics 5:277-291

van Bentem SDLF, Hirt H (2007) Using phosphoproteomics to reveal signalling dynamics in plants. Trends Plant Sci 12:404-411

Velini ED, Alves E, Godoy MC, Meschede DK, Souza RT, Duke SO (2008) Glyphosate applied at low doses can stimulate plant growth. Pest Manag Sci 64:489-496

Venturelli S, Belz RG, Kämper A, Berger A, von Horn K, Wegner A, Böcker A, Zabulon G, Lagenecker T, Kohlbacher O, Bameche F, Weigel D, Lauer UM, Bitzer M, Becker C (2015) Plants release precursors of histone deacetylase inhibitors to suppress growth of inhibitors. Plant Cell 27:3175-3189 
Vivancos PD, Driscoll SP, Bulman CA, Ying L, Emami K, Treumann A, Mauve C, Noctor G, Foyer CH (2011) Perturbations of amino acid metabolism associated with glyphosate-dependent inhibition of shikimic acid metabolism affect cellular redox homeostasis and alter the abundance of proteins involved in photosynthesis and photorespiration. Plant Physiol 157:256-268 Vogel JP, Garvin DF, Mockler TC, Schmutz J, Rokhsar D, Bevan MW, Barry K, Lucas S, Harmon-Smith M, Lail K, Tice H (2010) Genome sequencing and analysis of the model grass Brachypodium distachyon. Nature 463:763-768

Wang CS, Lin WT, Chiang YJ, Wang CY (2017) Metabolism of fluazifop-Pbutyl in resistant goosegrass (Eleusine indica) in Taiwan. Weed Sci 65: 228-238

Wang Z, Li Q, Zhao J, Peng Y (2011) Investigation of the effect of herbicide amprophos methyl on spindle formation and proteome change in maize by immunofluroscence and proteomic technique. Cytologia 76:249-259

Welti R, Shah J, Li W, Li M, Chen J, Burke JJ, Fauconnier M, Chapman K, Chye M, Wang X (2007) Plant lipidomics: discerning biological function by profiling plant complex lipids using mass spectrometry. Front Biosci 12:2494-2506

Wiersma AT, Gaines TA, Preston C, Hamilton JP, Giacomini D, Buell CR, Leach JE, Westra P (2015) Gene amplification of 5-enol-pyruvylshikimate3-phosphate synthase in glyphosate-resistant Kochia scoparia. Planta 241:463-474

Wright AA, Rodriguez-Carres M, Sasidharan R, Koski L, Peterson DG, Nandula VK, Ray JD, Bond JA, Shaw DR (2018a) Multiple herbicideresistant junglerice (Echinochloa colona): identification of genes potentially involved in resistance through differential gene expression analysis. Weed Sci 66:347-354

Wright AA, Sasidharan R, Koski L, Rodriguez-Carres M, Peterson DG, Nandula VK, Ray JD, Bond JA, Shaw DR (2018b) Transcriptomic changes in Echinochloa colona in response to treatment with the herbicide imazamox. Planta 247:369-379

Wu S, Tohge T, Cuadros-Inostroza Á, Tong H, Tenenboim H, Kooke R, Méret M, Keurentjes JB, Nikoloski Z, Fernie AR, Willmitzer L (2018) Mapping the Arabidopsis metabolic landscape by untargeted metabolomics at different environmental conditions. Mol Plant 11:118-134
Yadav N, Khurana SMP, Yadav DK (2015a) Plant secretomics: unique initiatives. Pages 357-384 in Barh D, Khan M \& Davies E eds., PlantOmics: The Omics of Plant Science. New Delhi: Springer

Yadav S, Yadav DK, Yadav N, Khurana SMP (2015b) Plant glycomics. Advances and applications. Pages 299-329 in Barh D, Khan M \& Davies E eds., PlantOmics: The Omics of Plant Science. New Delhi: Springer

Yang X, Yu X-Y, Li Y-F (2013) De novo assembly and characterization of the barnyardgrass (Echinochloa crus-galli) transcriptome using next-generation pyrosequencing. PLoS ONE 8:e69168

Yang X, Zhang Z, Gu T, Dong M, Peng Q, Bai L, Li Y (2017) Quantitative proteomics reveals ecological fitness cost of multi-herbicide resistant barnyardgrass (Echinochloa crus-galli L.). J Proteomics 150:160-169

Zhang Q, Reichers DE (2008) Proteomics: an emerging technology for weed science research. Weed Sci 56:306-313

Zhang X (2008) The epigenetic landscape of plants. Science 320:489-492

Zhao B, Huo J, Liu N, Zhang J, Dong J (2018) Transketolase is identified as a target of herbicidal substance $\alpha$-terthienyl by proteomics. Toxins 10:41

Zhao L, Hu Q, Huang Y, Fulton AN, Hannah-Bick C, Adeleye AS, Keller AA (2017a) Activation of antioxidant and detoxification gene expression in cucumber plants exposed to a $\mathrm{Cu}(\mathrm{OH}) 2$ nanopesticide. Environ Sci: Nano 4:1750-1760

Zhao L, Hu Q, Huang Y, Keller AA (2017b) Response at genetic, metabolic, and physiological levels of maize (Zea mays) exposed to a $\mathrm{Cu}(\mathrm{OH})_{2}$ nanopesticide. ACS Sustainable Chem Eng 5:8294-8301

Zhao L, Huang Y, Adeleye AS, Keller AA (2017c) Metabolomics reveals Cu $(\mathrm{OH})_{2}$ nanopesticide-activated anti-oxidative pathways and decreased beneficial antioxidants in spinach leaves. Environ Sci Technol 51:1018410194

Zhu J, Patzoldt WL, Radwan O, Tranel PJ, Clough SJ (2009) Effects of photosystem II-interfering herbicides atrazine and bentazon on the soybean transcriptome. Plant Genome 2:191-205

Zhu J, Patzoldt WL, Shealy RT, Vodkin LO, Clough SJ, Tranel PJ (2008) Transcriptome response to glyphosate in sensitive and resistant soybean. J Agric Food Chem 56:6355-6363 